\title{
DIGITALCOMMONS
}

@WAYNESTATE -

Wayne State University

3-6-2015

\section{Hemochromatosis: Niche Construction and the Genetic Domino Effect in the European Neolithic}

John M. McCullough

University of Utah, john.mccullough@anthro.utah.edu

Kathleen M. Heath

Indiana State University

Alexis M. Smith

University of Utah

\section{Recommended Citation}

McCullough, John M.; Heath, Kathleen M.; and Smith, Alexis M., "Hemochromatosis: Niche Construction and the Genetic Domino Effect in the European Neolithic" (2015). Human Biology Open Access Pre-Prints. Paper 74.

http://digitalcommons.wayne.edu/humbiol_preprints/74 


\title{
Hemochromatosis: Niche Construction and the Genetic Domino Effect in the European Neolithic
}

John M. McCullough ${ }^{1 *}$, Kathleen M. Heath ${ }^{1,2}$ and Alexis M. Smith ${ }^{3}$

${ }^{1}$ Department of Anthropology, 270 South 1400 East \# 102, Salt Lake City, UT, $84112-$ 0060, USA.

${ }^{2}$ Department of Earth and Environmental Systems, Indiana State University, Terre Haute, Indiana 47809, USA.

${ }^{3}$ Department of Anthropology, 270 South 1400 East \# 102, Salt Lake City, UT, $84112-$ 0060, USA.

*Correspondence to: John M. McCullough, Anthropology, University of Utah, 270 South 1400 East \#102, Salt Lake City, UT 84112-0060. Phone: 801-581-6251. E-mail: john.mccullough@anthro.utah.edu

Key words: Hemochromatosis, anemia, dairying, lactase persistence, European agricultural revolution

\begin{abstract}
Hereditary hemochromatosis $(\mathrm{HH})$ is caused by a potentially lethal recessive gene (HFE, $\mathrm{C} 282 \mathrm{Y}$ allele) that increases iron absorption and reaches polymorphic levels in Northern European populations. Because persons carrying the allele absorb iron more readily than non-carriers, it has often been suggested $H F E$ is an adaptation to anemia. We hypothesize
\end{abstract}


positive selection for $H F E$ began during or after the European Neolithic with the adoption of an iron-deficient high grain and dairying diet and consequent anemia, a finding confirmed in Neolithic and later European skeletons. HFE frequency compared with rate of lactase persistence in Eurasia yields a positive linear correlation coefficient of 0.86 . We suggest this is just one of many mutations that became common after the adoption of agriculture. 
Contrary to received wisdom (Gould 2000), the human genome is undergoing rapid evolutionary change (Hawks et al 2007; Hughes et al 2008; Perry et al 2007; Bryk et al 2008), especially loci related to the major shift in diet during food domestication and later (McCracken 1971; Perry et al 2007; Cochran and Harpending 2009). We suggest the hemochromatosis mutation is another polymorphic artifact of the Neolithic Revolution.

Hereditary hemochromatosis $(\mathrm{HH})$ is a potentially lethal disorder of iron metabolism based on a partially recessive gene (HFE; OMIM 235200. 6p22.2; 6p21.3) reaching polymorphic levels throughout western Eurasia, especially northwest Europe (Barton et al 2010; Enattah et al 2007; Merryweather-Clarke et al 2000; Cummings 2000). The disorder is characterized by increased levels of iron absorption and a gradual accumulation of excess iron stores in the liver and kidneys occasionally approaching lethal levels in homozygotes (Britton 2000). Heterozygotes have also slightly elevated levels of iron (Bulaj et al 1996: Edwards et al 2000, inter alia) but penetrance for clinical symptoms of HH is low in either zygosity (Waalen et al 2002).

The two most prevalent mutant alleles associated with hemochromatosis are the C282Y and H63D variants (Merryweather-Clarke et al 2000). The former allele is related to development of $\mathrm{HH}$ when inherited in the homozygous state but double heterozygotes of the two mutants may also produce increased iron levels (Cartwright et al 1979). Males are more often affected than females (Loreal et al 1992; Bulaj et al 1996). Clinical hemochromatosis may also develop from high levels of alcohol intake with or without presence of the HFE allele (Adams and Agnew 1996; Scotet et al 2003).

While excess iron poses an occasional threat to health, anemia is a more common and serious worldwide health problem (Greer and Arber 2014), characterized by lethargy, 
fatigue, weakness, poor concentration and dyspnea. Anemia affects the health of over 2 billion humans (Zimmermann and Hurrell 2007), costing up to a 4\% loss in world GDP (Horton and Ross 2003) and continues to be extremely common in developing countries (DeMaeyer and Adiels-Tegman 1985; Kohlmeier et al 1998). It is still observed in developed countries, such as the United Kingdom (Heath and Fairweather-Tait 2002), France (Hereberg et al 2001), Russia (Kohlmeier et al 1998) and the United States (Scholl 2005).

Mothers suffering anemia may be at risk for poor maternal outcomes or higher mortality (Brabin et al 2001a; Khan et al 2006). Babies born of anemic mothers are often underweight (World Health Organization 2008) and at risk for health problems (StuartMacadam 1989; Brabin et al 2001b). In a meta-analysis of 92 studies it was shown iron supplementation resulted in increased newborn weight (Haider et al 2013). Low birth weight infants in Europe had a lower frequency of the $\mathrm{C} 282 \mathrm{Y}$ allele than expected (Maier et al 1999). A counter-argument is that iron deficiency may serve as an adaptation to some infectious diseases such as malaria, plague and tuberculosis (Denic and Agarwal 2007).

Toomajian and Kreitman (2002) discovered that the C282Y allele was a young mutation at high frequency; his team later suggested it was due to rapid positive selection in an iron-deficient dietary environment (Toomajian et al 2003). Williamson et al (2007) disagreed, noting that the HFE allele is located in the area of chromosome 6 where the genes defining histones important in DNA synthesis are situated; Hartfield and Otto (2011) agreed with their interpretation and noted the importance of finding a lethal gene caught by linkage in a sweep for a beneficial gene, namely histones. Although not 
mentioned in either critical study, HFE is also closely linked with numerous HLA and other loci that must be the objects of selection (Apanius et al 1997).

Motulsky (1979) first suggested that the HFE mutation might be an adaptation to iron deficiency, and others have made similar suggestions (Rotter and Diamond 1987; Salter-Cid et al 1998; Fairbanks 2000; Toomajian et al 2003; Raddatz et al 2003). Denic and Agarwal (1999) first proposed the Neolithic Revolution as the historical event responsible for the presence of $H F E$. Naugler (2008) later hypothesized that the specific cause of anemia was adoption of a high grain diet. Phytates present on the surface of whole cereal grains and other seeds chelate dietary iron and several other minerals, making them physiologically unavailable (Committee on Food Protection, Food and Nutrition Board, National Research Council 1973; Hurrell 2003), thus increasing the risk of anemia.

We accept Naugler's phytate hypothesis but believe the total dietary shift of the Neolithic Revolution provides a broader bio-cultural context in which the incidence of anemia is expected to rise. While the increased ingestion of phytates decreases the physiological availability of ingested dietary iron, the partial substitution of iron-poor milk products for heme iron-rich meat as a major protein source further diminished iron ingestion.

The Northern European hunter-gatherer diet with traditional iron-rich high dependence on mammals and/or shellfish shifted to heavy dependence on grains and milk products in the Neolithic (Straus 1977; Cordain et al 2000; 2002). Red meat and many species of shellfish provide a rich source of highly digestible heme iron (U.S. Department of Agriculture, Agricultural Research Service. 2012). Conversely, bovid milk is virtually 
devoid of iron (Fox 1955; Pennington et al 1987), and calcium present in bovid milk inhibits iron ingestion (Baynes and Bothwell 1990).

The combination of reduced iron intake from the partial substitution of milk products for meat, in combination with the negative effects of phytates on mineral absorption, later compounded by the effect of increased parasitism associated with higher agricultural population densities (Gonçalves et al 2003) must have reduced effective iron ingestion among European agriculturalists which is first seen commonly in Neolithic skeletal material (e.g., Wittwer-Bachofen and Tomo 2008). We suggest this confluence of events resulted in a new set of diet-based pressures that created an environment ripe for anemia to develop among the early farmers, thereby making advantageous a mutation increasing iron absorption.

Thus, we hypothesize a strong statistical association between the geographic distributions of the allele frequencies of the $\mathrm{C} 282 \mathrm{Y}$ allele of hemochromatosis $(H F E)$ and phenotypic lactase persistence (LP) as a measure evolutionarily derived of historic milk dependence and population-wide adoption of European style agriculture in general.

\section{Materials and Methods}

To test this hypothesis we compared the frequency of the major mutant allele associated with $\mathrm{HH}(\mathrm{C} 282 \mathrm{Y})$, and the prevalence of phenotypic lactase persistence (LP). Our hypothesis is restricted to populations traditionally living in Eurasia and surrounding geographical zones. This would include Europe, proper, and nearby North Africa and Western and Southwestern Asia; four East Asian populations for which we have both 
HFE and LP data were also included for the sake of completeness but have little influence on the statistical outcome.

$H F E$ data for this study were taken from two major databases that include genetic data from European populations in Distante et al (2004) and Merryweather-Clarke et al (2000), as well as other sources published subsequently; a complete listing is found in Table 1.

Lactose tolerance data were taken from the University College, London, Global Lactase Persistence Association Database in May of 2013. (http//:www.ucl.as.uk/macelab/resources/glad/LP_phenotype and http//:www.ucl.as.uk/macelab/resources/glad/LP_genotype).

The HFE and LP geographic locations were linked as closely as possible. When HFE studies specified the study site, that location was used for comparison with the closest within-country location in the LP dataset. Our analysis relates specifically to populations most likely affected by or tested for the C/T (-13910*T) "European" allele of the LP gene. Much is known concerning the distribution of African and Arabian LP variants that have been well described in the literature, but there are too few available data regarding these variants from Europe to conduct a reliable analysis of their prevalence. Separate ethnic groups within countries such as the Saami, Basques and Roma (Gypsies) were considered independent of the national population.

In some cases there was only one datum for either the HFE or the LP frequencies. Where there were multiple studies done in a similar location we transformed the corresponding data to a single sample-weighted mean. For instance, for Northern Italians we had a single value for LP but numerous results for the $H F E$ allele; these latter were 
merged into a single sample-weighted value to compare with the sole LP value. In the case of Turks both the HFE and LP data were merged to present a single datum point for each (Table 2). Accumulating many small samples into a single value also had the advantage of reducing variability due to the random fluctuations inherent in small samples.

\section{Results}

There is a high positive linear relationship $\left(r=0.86\right.$; adjusted $r^{2}=0.68 ; t=9.23 ; F=$ 85.19 , d.f. $=41, \mathrm{p}<0.0001)$ between the frequency of the C282Y allele of $H F E$ and the prevalence of lactase persistence (Figure 1). The resulting regression equation is " $H F E$ $(\%)=-1.2838+0.0812(\mathrm{LP} \%) "$. The alternative mutation involved in hemochromatosis, $\mathrm{H} 63 \mathrm{D}$, is unrelated to $\mathrm{LP}\left(\mathrm{r}^{2}=0.030 ; \mathrm{p}=0.93\right)$. In an attempt to relate grain consumption to $\mathrm{C} 282 \mathrm{Y}$ frequencies we compared these to wheat per capita consumption rates in Europe (FAO 2007); the results demonstrated the lack of relationship between these rates and the HFE allele $(\mathrm{r}=0.014)$ and also LP $(\mathrm{r}=0.040)$.

Because we are comparing two genetic-based traits in the same species our results are obviously autocorrelated. To account for this statistical violation we followed the suggestion by Legendre (1993) and generated a series of partial correlation coefficients using 19 loci for which there are adequate national sample sizes for controls (Roychoudhury and Nei 1988). Despite many attempts at statistical correction the relationship between the $\mathrm{C} 282 \mathrm{Y}$ allele and LP remained strongly positive and significant (Table 3). 


\section{Discussion}

Niche Construction Theory posits that populations are adapted to stable surroundings, but should a change occur in the selection environment, the initial response to stress will likely be cultural or behavioral. If the cultural response is inadequate the next level of response is genetic (Laland and Brown 2002; 2006:95). Lactase persistence is one of the most obvious and widely cited cases of niche construction (e.g., Gerbault et al 2011). Here we propose that for agricultural Europeans the failure to provide a strong behavioral response to anemia led to a genetic adaptation that eventually allowed for more successful milk and grain utilization.

The Agricultural Revolution of 11,000 years ago initiated the most dramatic change in the human diet since the adoption of a high meat regimen some two million years earlier (Cordain et al 2002). At the time of the Neolithic Revolution a sudden dietary shift occurred, from the Paleolithic and Mesolithic hunter-gatherer foods with high independence on meat and/or shellfish (Stiner et al 2000; Cordain et al 2000; 2002; Eaton and Eaton 2000) that provide rich sources of iron (U.S. Department of Agriculture, Agricultural Research Service. 2012) to primary dependence on grain and milk products. The bio-archaeological record clearly demonstrates that human populations, European in particular, were highly dependent on meat or and seafood resources during the Late Paleolithic and were only slightly less so during for the Mesolithic (Price 2000; Richards et al 2005). These diets would have provided ample sources of iron and few sources of phytates so that iron-deficiency anemia would be expected to have been less common.

The switch to farming resulted in a shift in the diet from one higher in iron-rich foods to one higher in carbohydrates but poorer in iron. Bovid milk is virtually devoid of 
iron (Fox 1955; Pennington et al 1987). Additionally, calcium present in milk inhibits iron intake and iron ingestion from bovid milk, but lactoferritins present in human milk adequately supply the child with iron at a level two and a half times higher than from cow's milk (Hallberg et al 1992).

Fresh milk ingestion early in the Neolithic must have been difficult for adults but gradual increase of the lactase persistence (LP) allele, primarily the $-13910 \mathrm{C}>\mathrm{T}$ mutation allowing production of lactase beyond childhood, would have facilitated ingestion. Early on when the LP allele was in low frequencies reduction of lactose content could be accomplished by transformation of milk to yogurts, cheeses, butter and alcoholic beverages (Kolars et al 1984).

Once adopted, the transition to agriculture was extremely rapid and complete in Britain (Legge 1981, 2008; Brown 2007; Schulting and Richards 2002) and elsewhere in Northern Europe (Whittle 1996; Price 2000; Richards et al 2003; Bogaard and Jones 2007; Rowley-Conway 2011). Dates for the first evidence of dairying coincide with the first evidence of grain utilization in Britain. Both appear to have arrived around or slightly before approximately $4000 \mathrm{BC}$ and increased in prominence for the next thousand years (Brown 2007). Analysis of lipid residues in ceramic shards show evidence of fats derived from milk or milk products from the earliest Neolithic horizons (Copley et al 2003; Soberl and Evershed 2009). Later sites of Stanwick (Iron Age to Roman) and West Cotton (late Saxon to Medieval) show a substantial continuation of the dairying tradition (Dudd and Evershed 1998).

The archaeology of Central Europe paints a similar dietary history (Schibler 2006). The Arbon 3 site in Switzerland, dated to the Late Neolithic (3384-3370 BC) also 
shows signs of milk lipid residues on pottery (Spangenberg et al 2006). Other archaeological evidence for early milk processing in Central Europe has been found in ceramic sieves of the LBK Culture dating earlier than $4500 \mathrm{BC}$ that are similar to historic period strainers used to separate curd lumps from lactose-rich liquid whey (Bogucki 1984; Sherrat 1981) and may be an indicator of milk processing to a lower lactose product. Earliest dates for milk processing comes from Northwest Anatolia and southeastern Europe dated at 6000 to 6500 BC (Evershed et al 2008). The hooks of Galium aparine (Goosegrass), a plant commonly found in LBK Neolithic sites (Colledge et al 2005), was used by ancient Greek shepherds and modern Swedes as sieves to filter milk (Grieve 1971:207),

Plant sources of ascorbic acid may ameliorate negative effects of iron depletion by phytates. However, as farming spread from Southwest Asia into Central and Northwestern Europe, an increasingly impoverished version of the original Neolithic Crop Package is carried out of the Fertile Crescent. Only two of the five original grains, three of the original five pulses and about a third of the non-crop/weed taxa are found in LBK sites. Colledge et al (2005) ascribe this depletion to a combination of inhospitable northern climate and cultural preference. Because of the difficulty in sampling biases, they also only use a present/absent datum for plants at each site.

Colledge et al (2005) also note the difficulty in ascribing dietary roles to other plant remains that they cautiously call "other plants or weeds." Surely other plants were used either as foods or as medicines or ceremonially. Leafy plants must have been used in warmer seasons, but oxalates or other chelating compounds are commonly present in plants such as rhubarb or seeds such as acorns and may have been used sparingly. 
Conversely, many plant parts contain ascorbic acid that would have facilitated absorption of iron (Grieve 1971; Hopping and Ruliffson 1966).

Both the LP and HFE mutations appear at or after the adoption of milk-based agriculture in the Middle East or Europe, though estimates vary widely. The European lactose persistence gene $(-13910 \mathrm{C}>\mathrm{T})$ is dated from 8000 or 10,000 years BP (Holden and Mace 1997) to about approximately 4310-6730 years BP (Itah et al 2009) and the HFE C282Y mutation at from 1000 to 4000 years ago (Thomas et al 1998; Rochette et al 1999; Pietrangelo 2004; Ajioka et al 1997; Toomajian et al 2003) to over 6000 years ago (Distante et al 2004). Earlier, Raha-Chowdhury and Gruen (2000:87) found 23 mutations in 730 meioses, suggesting an age for the original C282Y mutation of approximately 200250 generations earlier, or roughly $6000+$ years ago, assuming 30 years per generation. If $H F E$ has been the subject of strong selection the more recent dates for mutation may be overly conservative (Maruyama 1974).

The earlier estimated mutation dates for $H F E$ would coincide with the arrival of agriculture in Britain or its earlier existence appearance on the continent (James 1997; Cunliffe 2003; Thomas 2003) and the Middle East. Klitz, et al (1992) estimated the ages of the HLA-A and HLA-B complexes which are closely-linked with HFE and concluded that their spread corresponds chronologically with the spread of agriculture from the Middle East, approximately 10,000 years ago (Sokal et al 1991). The extremely low frequencies of the $\mathrm{C} 282 \mathrm{Y}$ allele in the Mediterranean and Near East argue against an early farming origin in these regions. The H63D mutation is more widespread within the populations described, but exhibits a less structured distribution; it appears to be much older, having arisen several thousand years earlier (Rochette et al 1999; Candore et al 
2002). If the H63D geographical distribution resulted from positive selection, its spread would be relatable to an event independent of and earlier than dairying.

Two major bioarchaeological skeletal indicators of iron deficiency increase dramatically in the Early Neolithic relative to earlier periods (Stuart-Macadam 1998). Both porotic hyperostosis and cribra orbitalia appear to have been almost completely absent in the central European Mesolithic, but are common in the early Neolithic (Wittwer-Backofen and Tomo 2008). A similar pattern is observed in the Eastern Mediterranean (Angel 1984), Iraq and Iran (Rathbun 1984), Estonia (Jankauskas and Palubeckaité 2006) and the Ukraine, even before evidence of dense settlements that would be have been associated with increased parasitization (Zvelebil and Lillie 2000:81). Central European communities remained small for long periods and did not enlarge to the level of permanent towns until the Late Bronze Age, about 800-600 BC (Wells 1984:38). Urbanization did not arrive in the British Isles until the founding of Londinium by the Romans (Wells 2008:88-120).

These two bioarchaeological markers may indicate dietary deficiencies of either vitamin $\mathrm{C}$ (ascorbic acid) or iron. However, functionally the two nutrients are linked because vitamin $\mathrm{C}$ is important in iron ingestion and metabolism, and a decrease in vitamin $\mathrm{C}$ would leads to a reduction in the physiological bioavailability of iron (PromU-Thai 2006). Addition of vitamin C to the diet reduces the chelating effect of phytates on iron metabolism (Macfarlane et al 1988).

Another trend in skeletal morphology from Upper Paleolithic to Neolithic in Europe is a steady decrease in stature (Meiklejohn and Babb 2011) and has also been reported as a general trend elsewhere (Ruff 2002), but because a number of competing 
environmental stresses may result in a generalized decrease in stature, by itself this cannot be considered a definitive indicator of nutritional inadequacy (Brues 1959; Frayer 1981). However, in New World populations the most significant skeletal factor associated with stature suppression is anemia (Steckel et al 2002). The role of iron in stature diminution is not known. Because iron is found in bone collagen rather than in the mineral portion of bone (Klepinger 1984; Ezzo 1994), it is likely to be involved in the growth process. Recently Cippa and Krayenbuehl (2013) found that Swiss male and female $\mathrm{C} 282 \mathrm{Y}$ homozygotes on average were 4.3 and $3.3 \mathrm{~cm}$ taller, respectively, than age- and sex-matched controls suggesting an important role of hemochromatosis, and by implication, iron in growth. Iron is water-soluble and is rapidly leached from or absorbed into bone after death making paleo-osteological analysis of bone for iron content dubious (Klepinger 1984).

Parasites form a significant risk for iron loss and anemia in modern, densely settled populations (Kent 1986; Awasthi and Bundy 2007). Early to Middle Neolithic settlements in Central Europe seem to have consisted primarily of isolated households or small groups of houses, but by Late Neolithic some settlements appear to have experienced a rapid growth in size and density (Bogaard 2004:11,13, 16-17). The incidence of parasitism as an aggravating factor would be expected to intensify through the Neolithic as population densities rose and settlements were inhabited for longer periods of time, resulting in an additional factor contributing to dietary stress (Holland and O'Brien 1997; Gonçalves et al 2003). The extent of this effect is difficult to measure, but should not be forgotten. However, paleopathological signs of anemia appear in the European Neolithic context well before settlement size and density could be considered 
to have been major factors affecting the frequency of the skeletal indicators of dietary stress discussed above. (Zvelebil and Lillie 2000:81).

Iron may leach from cooking vessels and provide an indirect dietary source. While the Early Iron Age began in Central Europe at $600 \mathrm{BC}$, bronze and ceramic remained the primary materials for cooking vessels until after $400 \mathrm{BC}$ when iron became readily available (Wells 1984:119, 135). Despite the widening use of iron vessels, indicators of anemia continued to be present in archaeological and European historical populations through the $19^{\text {th }}$ century, as in continental Roman (Miritoiu 1992), British Roman and Medieval (Stuart-Macadam 1991; Wells 1982; Lewis 2002; Roberts and Cox 2003; Hart and Holbrook 2011) and industrial (Molleson and Cox 1993; Lewis 2002) skeletal series with some pre-adult series showing cribra orbitalia frequencies between 50 and $60 \%$ in children (Lewis 2002).

In the Middle East and Eastern Mediterranean cribra orbitalia values vary from $0 \%$ in the Iranian Paleolithic to $100 \%$ in the Levant Neolithic; no post-Paleolithic sample had a value less than $8 \%$ and most were in the $20-40 \%$ range (Papathanassiou 2005). Greek Neolithic series have the cribra orbitalia and porotic hyperostosis lesions reaching prevalences of $40 \%$ to $50 \%$ (Papathanasiou 2003). A small Polish skeletal series yielded cribra orbitalia frequencies of $59 \%$ for the Neolithic and $44 \%$ for the Early Bronze samples (Glén-Haduch et al 1997).

Hemochromatosis is not found among East African herders who do utilize milk and, have a different LP lactase persistence mutation, thus possibly indicating an independent milking and dairying history. The frequency of anemia in these populations is not expected to be present at the levels observed in European and Europe-adjacent 
populations, due at least in part, to the practice of mixing bovine blood with milk before ingestion (Little and Leslie 1999), thus fortifying iron-poor milk with a supply of ironrich blood. Here a cultural adaptation has eliminated the necessity for a genetic resolution, as predicted by Laland and Brown $(2006: 95 ; 2012)$. It appears that Africans were able to directly solve the anemia problem culturally while Europeans may not have done so.

While over three quarters of hemochromatosis patients are homozygotes for the C282Y allele, among Europeans the vast majority of alleles are carried by C282Y/wt heterozygotes, a ratio of approximately 23.5:1 (9.2/0.4). If double heterozygotes $(\mathrm{C} 282 \mathrm{Y} / \mathrm{H} 63 \mathrm{D})$ are included the ratio increases to 27.5:1 (9.2 + 1.8/.4) (Hanson et al 2001). Thus, selection will have the most likely opportunity to act on the heterozygote phenotype.

$H F E$ induces higher absorption of iron into the body than the wild-type ("wt") allele. This is so in the homozygous state $(282 / 282)$, double heterozygous state $(282 / 63)$ and, to a lesser so extent, also in the heterozygous state (282/wt) (Cartwright et al 1979; Raddatz et al 2003).

Iron dietary absorption is similar in wt or heterozygote C282Y carriers, although the studies have included only very small sample sizes. Roe et al (2005) found no significant differences in most absorption measures but heterozygotes had consistently higher pre-test values (initial serum iron 11\%, serum ferritin 13\% and transferrin saturation $13 \%$ higher) and increased post-test intake of Fe-57 (12\%) and Fe-54 (8\%); they noted that increasing sample size from their 30 subjects to 332 would yield statistically significant results. Heterozygotes also had a significantly increased ability to 
absorb non-heme iron but not heme iron. In a meat-deficient diet non-heme iron would be the significant or major source of iron (Roe et al 2005).

Heterozygotes have serum iron concentrations $17 \mu \mathrm{g} / \mathrm{dL}$ higher and mean transferrin saturation $9 \%$ higher than $\mathrm{wt} / \mathrm{wt}$ homozygotes. In both measures there is a progressive increase in values from wt/wt, H63D/wt, C282Y/wt, H63D/H63D, $\mathrm{C} 282 \mathrm{Y} / \mathrm{H} 63 \mathrm{D}$ and $\mathrm{C} 282 \mathrm{Y} / \mathrm{C} 282 \mathrm{Y}$ genotypes; the increase is especially noticeable in the last two genotypes (Bulaj et al 1997; Edwards et al 2000; Adams et al 2005).

Blood iron levels are highest in homozygotes but are also elevated in heterozygotes. Mean ferritin levels are the best estimate of body iron stores, (McDonnell and Witte 1997), and are closely associated with clinical manifestations (Bradley, Hadlow and Palomaki 1996). The proportion of ferritin levels are significantly elevated in heterozygous males 31 to 60 years old and females 31 to 90 years old. In other 30 -year groups there are no significant differences between heterozygotes and wt homozygotes. Serum iron and transferrin saturation are both higher in heterozygotes for all age categories from 1 to 90 in both sexes (Cartwright et al 1979; Bulaj et al 1996).

Proportion of individuals with anemia (sub-normal serum ferritin concentrations of $<12 \mu \mathrm{g} / \mathrm{L}$ ) is lower in female heterozygotes than $\mathrm{wt} / \mathrm{wt}$ normals ( $21 \%$ vs. $32 \%$, respectively; $p=0.02$ ). In males $2 \%$ of heterozygotes have low serum ferritin concentrations compared with $4 \%$ of normal, a result not statistically significant $(\mathrm{p}=$ 0.44) (Edwards et al 2000; Bulaj et al 1996). Iron deficiency is less common in heterozygous women in screening tests conducted in California and Australia; (Rossi et al 2000; Rossi et al 2001; Beutler et al 2000). 
Heterozygotes almost never present clinically but there are two possible effects that may be triggered by environmental factors, especially high levels of alcohol consumption. One is direct damage by an elevated iron concentration and the other is ailments associated with hemochromatosis homozygotes (hepatic fibrosis, steatohepatitis, diabetes, and arthritic pain and associated arthritic symptoms) (Barton et al 1994).

To summarize, heterozygotes have slightly but significantly elevated values of iron storage and circulation but little evidence of pathological sequelae. Fewer heterozygous women are anemic but men show no difference.

While increased iron intake uptake is almost universal in C282Y heterozygotes and homozygotes, today few die from symptoms related to hemochromatosis. During adulthood, especially after age 40 , the excess iron accumulation in the tissues of the body can produce the serious or potentially lethal sequelae of classic hemochromatosis: including general fatigue, cirrhosis, liver fibrosis and cancer, cardiac disease, changes in pigmentation, orthopedic complications, and, in men, reduced libido and impotence (Adams et al 1997; Buettler et al 2002; Kelly et al 1984). Manifestation of these clinical symptoms is extremely variable presenting clinically in $1.2 \%$ of homozygotes or less (McCune et al 2002; Anderson et al 2004). Indeed, while increased iron intake is almost universal for all carriers, they rarely present clinically in either the homozygous (Beutler et al 2002) or heterozygous (Bulaj et al 1996) states. Thus, there is high penetrance for increased iron absorption, but low penetrance for manifestation of clinical symptoms (Adams and Barton 2007).

Severity of symptoms depends upon whether the mutation is found on an ancestral haplotype (Barton et al 1996; Piperno et al 1996), the presence of other 
modifying genetic factors (e.g., Merryweather-Clarke et al 2003; Pelucchi et al 2012; Livesey et al 2004) and environmental influences such as alcoholism (Adams and Agnew 1996; Adams and Barton 2007).

Health-affecting symptoms seldom manifest before age 40 , so that reproductive capacity is not negatively affected in the most productive years (Edwards et al 2000). The beneficial effects of carrying some variety of the HFE mutation are probably manifested in the early and reproductive years. Although survival even beyond the childbearing years can have a positive effect on evolutionary success (Hawkes 2003, 2004; Kaptijn et al 2010) selection preferentially favors attributes that directly influence generative capacity during reproductive years. These chronic conditions associated with hemochromatosis may have a negative influence late in life, but not until after the majority of the childbearing years have passed. Thus, a balance between the positive effects of increased iron early in life and negative effects of clinical manifestations in middle to late adulthood may be struck.

Despite the increasing risk of clinical sequelae with age, there may be no additional risk of death. Studies in France (Coppin et al 2003), Holland (Van Aken et al 2002), Germany (Niederau et al 1996; Niederau et al 1985), Italy (Fargion et al 1992) and Canada (Adams et al 1991) found no change in proportion of $H F E$ carriers in the population with advancing age and thus weak selection against them.

A problem with our analysis is the absence of LP data from major European countries. While we have HFE data for Norway, Iceland, Holland, Switzerland, Spain and Portugal, we have no LP information for comparison. We may guess the appropriate values, but having the actual data would be extremely useful as a retest of our hypothesis. 


\section{Conclusions}

Both the C282Y HFE allele and LP phenotype are more common in Northwestern Europe where bovid dairying practices are ancient and widespread (Beja-Pereira et al 2003) and reduced in southern Europe where fresh milk products are have historically been more difficult to preserve and less commonly consumed (Kindstedt 2012:12).

Dairying became a major food source in the European Neolithic. Before mutation of the LP locus, maximum utilization of unprocessed milk was not possible, but with the mutation of the LP locus it became so (Gerbault et al 2011). Unless artificially fortified, non-human sources of milk are deficient in iron. As soon as there is evidence of early dairying in Europe there is strong evidence of iron deficiency in skeletons of the same period, in the form of porotic hyperostosis and/or cribra orbitalia. As iron-deficiency anemia is a potentially life-threatening condition, we suggest that the $\mathrm{C} 282 \mathrm{Y}$ mutation of the $H F E$ gene, which induces higher absorption of iron into the body than the wild-type ("wt") allele, was an advantageous change in the genome in the dietary context arising in the Neolithic and that this fact explains why HFE is so common in areas in which milk ingestion has been historically common.

In conclusion, despite ethnic-based hypotheses regarding the origin and spread of the HFE C282Y variant (Whittington 2006, Milman and Pedersen 2003, inter alia) we suggest the high prevalence of hemochromatosis is directly related to the adoption of dairying and phytate-heavy grains in the northern Europe diet, where genes increasing iron absorption were favored after foraging was abandoned for the lure of high carbohydrate production and the more productive utilization of milk. In addition, this 
adaptation is potentially a balanced polymorphism, trading the advantage of anemia avoidance in youth and early adulthood with potentially lethal pathology late in life for a small proportion of affected individuals.

The genes associated with hemochromatosis and lactase persistence are only two of a number of loci that have been seriously affected by the adoption of agriculture. Other notable examples are the increased number of amylase repeats (Perry et al 2007) and milk proteins in cattle (Beja-Pereira et al 2003). It seems clear that there are many other falling ancestral dominos to be discovered in this evolutionary cascade precipitated by agriculture in Northern Europe and elsewhere (Cochran and Harpending 2009; Voight et al 2006; Wang et al, 2006; Weinberg 1999).

\section{Acknowledgments}

We thank the reviewers and editors for comments that substantially improved the final manuscript.

Received 16 July 2014; revision accepted for publication 7 July 2015.

\section{Literature Cited}

Adams, P. C., and S. Agnew. 1996. Alcoholism in hereditary hemochromatosis revisited: Prevalence and clinical consequences among homozygous siblings. Hepatology $23: 724-727$.

Adams, P. C., and J. C. Barton. 2007. Hemochromatosis. The Lancet 370:1855-1860. 
Adams, P. C., Y. Deugnier, R. Moirand et al. 1997. The relationship between iron overload, clinical symptoms, and age in 410 patients with genetic hemochromatosis. Z. Hepatol. 25(1):162-166.

Adams, P. C., D. M. Reboussin, J. C. Barton et al. 2005. Hemochromatosis and iron overload screening in a racially diverse population. N. Engl. J. Med. 352:17691778.

Adams, P. C., M. Speechley and A. E. Kertesz. 1991. Long-term survival analysis in hereditary hemochromatosis. Gastroenterology 101:368-372.

Aguilar Martinez, P., C. Biron, F. Blanc et al. 1997. Compound Heterozygotes for Hemochromatosis Gene Mutations: May They Help to Understand the Pathophysiology of the Disease? Blood Cells. Mol. Dis. 23(2):269-276.

Ajioka, R. S., L. B. Jorde, J. R. Gruen et al. 1997. Haplotype analysis of hemochromatosis: Evaluation of different linkage-disequilibrium approaches and the evolution of disease chromosomes. Am. J. Hum. Genet. 60:1439-1447.

Anderson, R. V., A. Tybjaerg-Hansen, M. Appleyard et al. 2004. Hemochromatosis mutations in the general population: Iron overload progression rate. Blood $103: 2914-2919$.

Andrikovics H, I. Klein, L. Kalmár et al. 1999. [A new method of molecular testing in the differential diagnosis of hereditary hemochromatosis]. [Article in Hungarian] Orv. Hetil. 140:2517-22.

Angel, J. L. 1984. Health as a crucial factor in the changes from hunting to 
developed farming in the Eastern Mediterranean. In: Paleopathology at the Origins of Agriculture, M. N. Cohen and G. L. Armelagos, eds. Orlando, FL: Academic Press. 51-73.

Apanius, V., D. Penn, P. R. Slev et al. 1997. The nature of selection on the major histocompatibility complex. Crit. Rev. Immunol. 17 (2): 179-224.

Awasthi, S. and D. Bundy. 2007. Intestinal nematode infection and anaemia in developing countries. B. M. J. 334:1065-1066.

Baiget, B., M. J. Barceló, and E. Gimferrer. 1998. Frequency of the HFE C282Y and H63D mutations in distinct ethnic groups living in Spain. J. Med. Genet. 35:701.

Barton, J. C., L. Harmon, C. Rivers et al. 1996. Hemochromatosis: Association of severity of iron overload with genetic markers. Blood Cells. Mol. Dis. 22:195204.

Barton, J. C., C. Q. Edwards, D. Pradyumna et al. eds. 2010. Handbook of Iron Overload Disorders. Cambridge: Cambridge University Press.

Barton, J. C., M. A. Patton, C. Q. Edwards et al. 1994 Blood lead concentrations in hereditary hemochromatosis. J. Lab. Clin. Med. 124:193-198.

Barut, G., H. Balci, M. Bozdayi et al. 2003. Screening for iron overload in the Turkish population. Digestive Diseases 21:279-285.

Baynes, R. D. and T.H. Bothwell. 1990. Iron Deficiency. Annu. Rev. Nutrition 10:133148.

Beckman L. E., N. Saha, V. Spitsyn et al. 1997. Ethnic differences in the HFE codon 282 (Cys/Tyr) polymorphism. Hum. Hered.47:263-267. 
Beckmann, L. E., K. Sjoberg, S. Eriksson et al. 2001. Haemochromatosis gene mutations in Finns, Swedes and Swedish Saamis. Hum. Hered. 52:110-112.

Beutler, E., V. Felitti, T. Gelbart et al. 2000. The effect of HFE genotypes on measures of iron overload in patients attending a health appraisal clinic. Ann. Intern. Med. 133:329-337.

Beutler E., V. J. Felitti, J. A. Koziol et al. 2002. Penetrance of $845 \mathrm{G} \rightarrow$ A(C282Y) HFE hereditary haemochromatosis mutation in the USA. Lancet 359:211-218.

Beja-Pereira, A., G. Luikart, P. R. England et al. 2003. Gene-culture coevolution between cattle milk protein genes and human lactase genes. Nat. Genet. 35:311-313.

Bogaard, A. 2004. Neolithic Farming in Central Europe: An Archaeobotanical Study of Crop Husbandry Practices. New York: Routledge.

Bogaard, A. and G. Jones 2007. Neolithic farming in Britain and Central Europe: Contrast or continuity? In Going Over: The Mesolithic-Neolithic transition in Northwest Europe. A. Whittle and V. Cummings, eds. London. British Academy. $357-375$.

Bogucki, P. 1984. Ceramic sieves of the Linear Pottery Culture and their economic implications. Oxford Journal of Archaeology 3:15-30.

Bogucki, P. 1986. The antiquity of dairying in temperate Europe. Expedition 28:51-58.

Borgna-Pignatti C., A. Solinas, C. Bombieri et al. 1998. The haemochromatosis mutations do not modify the clinical picture of thalassaemia major in patients regularly transfused and chelated. Br. J. Haematol. 103:813-816.

Borot, N., M. Roth, L. Malfroy, et al. 1997. Mutations in the MHC class I-like candidate gene for hemochromatosis in French patients. Immunogenetics 45:320-324. 
Brabin, B. J., M. Hakimi and D. Pelletier. 2001a. An analysis of anemia and pregnancyrelated maternal mortality. J. Nutr. 131:604S-614S

Brabin, B. J., Z. Premy and F. H. Verhoeff. 2001b. An analysis of anemia and child mortality. J. Nutr. 131:636S-645S.

Bradley, L.A., J. E. Hadlow, and G.E. Palomaki. 1996. Population screening for hemochromarosis: Expectations based on a study of relatives of symptomatic probands. J. Med. Screen. 3:171-177.

Braun, J., H. Donner, K. Plock et al. 1998. Hereditary hemochromatosis mutations (HFE) in patients with type 2 diabetes mellitus. Diabetologia 41:983-984.

Britton, R. S. 2000 Mechanisms of iron toxicity. In: Hemochromatosis: Genetics, Pathophysiology, Diagnosis and Treatment. J. C. Barton, and C. Q. Edwards, eds. Cambridge: Cambridge University Press. 229-238.

Brown, A. 2007. Dating the onset of cereal cultivation in Britain and Ireland: The evidence from charred cereal grains. Antiquity 81:1042-1052.

Brues, A. M. 1959. The spearman and the archer. Am. Anthropol. 61:457-469.

Bryk, J., E. Hardouin, I. Pugach et al. 2008. Positive selection in East Asians for an EDAR allele that enhances $\mathrm{NF}_{-\mathrm{k}} \mathrm{B}$ activation. PLoS One 3IE2209.

Bulaj, Z. J., L. M. Griffin, L. B. Jorde et al. 1996. Clinical and biochemical abnormalities in people heterozygous for hemochromatosis. N. Engl. J. Med. 335:1799-1805. Byrnes, V., E. Ryan, S. Barrett et al. 2001. Genetic Hemochromatosis, a Celtic Disease: Is It Now Time for Population Screening? Genet. Test. 5: 127-130. 
Campbell, S., D. K. George, S. D. Robb, et al. 2003. The prevalence of haemochromatosis gene mutations in the West of Scotland and their relation to ischemic heart disease. Heart 89:1023-1026.

Campo, S., T. Restuccia, D. Villari et al. 2001. Analysis of haemochromatosis gene mutations in a population from the Mediterranean Basin. Liver 21:233-236.

Carella, M., L. D'Ambrosio, A. Totaro et al. 1997. Mutation analysis of the HLA-H gene in Italian hemochromatosis patients. Am. J. Hum. Genet. 60: 828-832.

Candore, G., V. Mantovani, C. R. Balistreri et al. 2002. Frequency of the HFE gene mutations in five Italian populations. Blood Cells Mol. Dis. 29:267-273.

Cardoso, E. M., P. Stal, K. Hagen, et al. 1998. HFE mutations in patients with hereditary hemochromatosis in Sweden. J. Intern. Med. 243:203-208.

Stefano Cassanelli, S., E. Pignatti, G. Montosi et al. 2001. Frequency and biochemical expression of $\mathrm{C} 282 \mathrm{Y} / \mathrm{H} 63 \mathrm{D}$ hemochromatosis (HFE) gene mutations in the healthy adult population in Italy. J. Hepatol. 34:523-528.

Cartwright G., C. Q. Edwards, K. Kravitz et al. 1979. Hereditary hemochromatosis:

Phenotypic expression of the disease. N. Engl. J. Med. 301:175-179

Cassanelli, S., A. Carbonieri, E. Baldini et al. 2001. Frequency and biochemical expression of $\mathrm{C} 282 \mathrm{Y} / \mathrm{H} 63 \mathrm{D}$ hemochromatosis (HFE) gene mutations in the healthy adult population in Italy. J. Hepatol. 34:523-528.

Chang, J. G., T. C. Liu, and, S. F. Lin. 1997. Rapid diagnosis of the HLA-H gene Cys 282 Tyr mutation in hemochromatosis by polymerase chain reaction - a very rare mutation in the Chinese population. Blood 89:3492-3493. 
Cimburova, M., I. Putova, H. Provaznikova et al. 2002. Hereditary hemochromatosis: Detection of $\mathrm{C} 282 \mathrm{Y}$ and H63D mutations in HFE gene by means of Guthrie Cards in population of Czech Republic. Genet. Epidemiol. 23(3):260-263. Cippa, PE and P.-A Krayenbuehl. 2013. Increased height in HFE hemochromatosis (Letter). N. Engl. J. Med. 369:785-786.

Cochran, G. and H. Harpending. 2009. The 10,000 Year Explosion. New York: Basic Books.

Colledge, S., J. Connolly and S. Shennan. 2005. The evolution of Neolithic farmimg from SW Asia origins to NW European limits. Eur. J. Archael. 8:137-156.

Committee on Food Protection, Food and Nutrition Board, National Research Council. 1973. "Phytates". Toxicants Occurring Naturally in Foods. National Academy of Sciences. $363-371$.

Copley, M. S., R. Berstan, S. N. Dudd et al. 2003. Direct chemical evidence for widespread dairying in prehistoric Britain. Proc. Natl. Acad. Sci., U. S. 100:1524-1529.

Coppin H., M. Bensaid S. Fruchon et al. 2003. Longevity and carrying the C282Y mutation for haemochromatosis on the HFE gene: Case control study of 492 French centenarians. Brit. Med. J. 327:132-133.

Cordain, L., S. B. Eaton, J. B. Miller et al. 2002. The paradoxical nature of huntergatherer diets: meat-based, yet non-atherogenic. Eur. J. Clin. Nutr. 56, Suppl 1, S42-S52. 
Cordain, L., J. B. Miller, B. Eaton et al. 2000. Plant-animal subsistence ratios and macronutrient energy estimations in worldwide hunter-gatherer diets1'2. Am. $J$. Clin. Nutr. 71:682-692.

Costarelli, S., C. Torti, L. B. Gatta et al. 2007. No Evidence of Relation Between Peripheral Neuropathy and Presence of Hemochromatosis Gene Mutations in HIV-1-Positive Patients. J. Acquir. Immune. Defic. Syndr: 46(2):255-256.

Cummings, M. R. 2000. Human Heredity: Principles and Issues. $5^{\text {th }}$ ed. Pacific Grove. Brooks/Cole.

Cunliffe, B. 2003. The Ancient Celts. Oxford. Oxford University Press.

Datz C., M. R. Lalloz, W. Vogel et al. 1997. Predominance of the HLA-H Cys282Tyr mutation in Austrian patients with genetic haemochromatosis. J. Hepatol. 27(5):773-779.

DeMaeyer, E. and M. Adiels-Tegman. 1985. The prevalence of anemia in the world. World Health Stat. Q. 38:303-316.

Denic, S. and M. M. Agarwal. 2007. Nutritional iron deficiency: An evolutionary perspective. Nutrition 23:6-14.

Distante, S., K. J. H. Robson, J. Graham-Campbell et al. 2004. The origin and spread of the HFE-C282Y haemochromatosis mutation. Hum. Genet. 115:269-279.

Dudd, S. N. and R. P. Evershed. 1998. Direct demonstration of milk as an element of archaeological economies. Science 282:1478-1481.

Eaton, S. B. and S. B. Eaton, III. 2000. Paleolithic vs. modern diets - selected pathophysiological implications. Eur. J. Nutr. 39:67-70. 
Edwards, C. Q., L. M. Griffen, Z. J. Bulaj et al. 2000. The iron phenotype of hemochromatosis heterozygotes. In: Hemochromatosis: Genetics, Pathophysiology, Diagnosis and Treatment. J. C. Barton and C. Q. Edwards, eds. Cambridge: Cambridge University Press. 411-418.

Ellervik, C., T. Mandrup-Poulsen, B. G Nordestgaard et al. 2001. Prevalence of hereditary haemochromatosis in late-onset type 1 diabetes mellitus: a retrospective study, Lancet, 358:1405-1409.

Enattah N. S., A. Trudeau, V. Pimenoff et al. 2007. Evidence of still-ongoing convergence evolution of the lactase persistence T(-13910) alleles in humans. Am. J. Hum. Genet. 81:615-625.

Evershed, R. P., S. Payne, A. G. Sherrat et al. 2008. Earliest date for milk use in the Near East and Southeastern Europe Linked to cattle herding. Nature 455:528-531.

Ezzo, J. A. 1994. Putting the 'chemistry' back into archaeological chemistry analysis: Modeling potential paleodietary indicators. J. Anthropol. Archaeol. 13:1-34.

Fairbanks, V. F. 2000. Hemochromatosis: Population genetics. In: Hemochromatosis: Genetics, Pathophysiology, Diagnosis and Treatment, J. C Barton and C. Q. Edwards, eds. Cambridge: Cambridge University Press, 42-50.

FAO 2007 HTTP://faostat.fao.org/faostat/\&nbsp; accessed Sep 2007.

Fargion, S., C. Manelli, A. Piperno et al. 1992. Survival and prognostic factors in 212 Italian patients with genetic hemochromatosis. Hepatology 15:655-669.

Floreani, A., E. R. Rizzotto, D. Basso et al. 2007. An open population screening study for $H F E$ gene major mutations proves the low prevalence of $\mathrm{C} 282 \mathrm{Y}$ mutation in Central Italy. Aliment. Pharmacol. Ther. 26:577-586. 
Fox, P. F. 1955. Advanced Dairy Chemistry, Vol. 3: Lactose, Water, Salts and Vitamins. 2nd ed. New York: Chapman and Hall.

Frayer, D. W. 1981. Body size, weapon use, and natural selection in the European Upper Paleolithic and Mesolithic. Am. Anthropol. 83:57-73.

Gabriková D., J. Bernasovská, S. Mačeková et al. 2012. Unique frequencies of HFE gene variants in Roma/Gypsies. J. Appl. Genet. 53:183-7.

Gerbault, P., A. Liebert, Y. Itan et al. 2011. Evolution of lactase persistence: An example of human niche construction. Phil. Trans. R Soc. (B) 366:863-877.

Global Lactase persistence Association Database. 2013. Available online at: http://www.ucl.ac.uk/mace-lab/resources/glad.

Glén-Haduch, E., K. Szostek, and H. Glab. 1997. Cribra orbitalia and trace element content in human teeth from the Neolithic and Early Bronze Age graves in Southern Poland. Am. J. Phys. Anthrop. 103:201-207.

Gonçalves M. L. C., A. Araújo, and L. F. Ferreira. 2003. Human intestinal parasites in the past: New findings and a review. Mem. Inst. Oswaldo Cruz 98(Suppl 1):103118.

Gottschalk, R., C. Seidi, T. Löffler et al. 1998. HFE codon 63/282 (H63D/C282Y) dimorphism in German patients with genetic hemochromatosis. Tissue Antigens 51(3):270-275.

Gottschalk, R., C. Seidl, S. Schilling et al. 2000. Iron-overload and genotypic expression of HFE mutations $\mathrm{H} 63 \mathrm{D} / \mathrm{C} 282 \mathrm{Y}$ and transferrin receptor Hin6I and BanI polymorphism in German patients with hereditary haemochromatosis. Eur. J. Immunogenet. 27:129-134. 
Gould, S. J. 2000 The spice of life. Leader to Leader 15:14-19.

Greer, J. P and D. A. Arber, eds. 2014. Wintrobe's Clinical Hematology. $13^{\text {th }}$ ed. Philadelphia: Lippincott Williams and Wilkins..

Grieve, M. 1971 (1931). A Modern Herbal: The Medicinal, Culinary, Cosmetic and Economic Properties, Cultivation and Folklore of Herbs, Grasses, Fungi, Shrubs \& Trees with All Their Modern Scientific Uses. Vol 1. Mineola, NY: Dover Publications.

Grove, J., A. K. Daly, A. D. Burt et al. 1998. Heterozygotes for HFE mutations have no increased risk of advanced alcoholic liver disease. Gut 43:262-266.

Haider, B. A., I. Olofin, M. Wang et al. 2013. Anaemia, prenatal iron use, and risk of adverse pregnancy outcomes: Systematic review and meta-analysis. B. M. J. 346:f3443.

Hallberg L., L. Rossander-Hultén, M. Brune et al. 1992. Bioavailability in man of iron in human milk and cow's milk in relation to their calcium contents. Pediatr. Res. $31: 524-527$.

Hanson E. H., G. Imperatore, and W. Burke. 2001. HFE gene and hereditary hemochromatosis: A HuGE review. Am. J. Epidemiol. 154:193-206.

Hart, J. and N. Holbrook. 2011. A Medieval monastic cemetery within the precinct of Malmesbury Abbey: Excavations in the Old Cinema Site, Market Cross. Wiltshire Archaeological and Natural History Magazine 104:166-192.

Hartfield, M. and S. P. Otto. 2011. Recombination and hitchhiking of deleterious alleles. Evolution 65:2421-2434. 
Hawks, J., E. T. Wang, G. M. Cochran et al. 2007. Recent acceleration of human adaptive evolution. Proc. Natl. Acad. Sci. U. S. A. 104:20753-20758.

Hawkes, K. 2003. Grandmothers and the evolution of human longevity. Am. J. Hum. Biol. 15:380-400.

Hawkes, K. 2004. Human longevity: The grandmother effect. Nature 428:128-129.

Heath, A. L. and S. J. Fairweather-Tait. 2002. Clinical implications of changes in the modern diet: Iron intake, absorption and status. Best Pract. Res. Clin. Haematol. $15: 225-241$.

Hellerbrand, C., A. K. Bosserhoff, S. Seegers et al. 2001. Mutation Analysis of the HFE Gene in German Hemochromatosis Patients and Controls using Automated SSCP-based Capillary Electrophoresis and a New PCR-ELISA Technique. Scand. J. Gastroenterol. 36:1211-1216.

Hereberg, S., P. Preziosi, and P. Galan. 2001. Iron deficiency in Europe. Public Health Nutr. 41:537-545.

Höhler, T., S. Leininger, H. H. Köhler et al. 2000. Heterozygosity for the hemochromatosis gene in liver diseases--prevalence and effects on liver histology. Liver 20(6):482-486.

Holmström, P., J. Marmur, G. Eggertsen et al. 2002. Mild iron overload in patients carrying the HFE S65C gene mutation: A retrospective study in patients with suspected iron overload and healthy controls. Gut 51:723-730.

Holden, C. J. and R. Mace. 1997. Phylogenetic analysis of the evolution of lactose digestion in adults. Hum. Biol., 69:605-628. 
Holland T. D. and M. J. O’Brien. 1997 Parasites, porotic hyperostosis and the implications of changing perspectives. Am. Antiq. 62:183-193.

Hopping, E. B. and W. S. Ruliffson. 1966. Roles of citric and ascorbic acids in enteric iron absorption in rats. Am. J. Physiol. 210:1316-1320.

Horton, S. and J. Ross. 2003. The economics of iron deficiency. Food Policy 28:51-75.

Hrachovinova I., B. Rypackova and D. Vyoral. 1999. Lack of association between hemochromatosis and factor V Leiden mutations in the Czech population. Thromb. Haemost. 82(3):1197-8.

Hughes, D. A., T. Kun, R. Strotmann et al. 2008. Parallel selection on TRPV6 in human populations. PLoS One 3:e1686.

Hurrell R. F. 2003. Influence of Vegetable Protein Sources on Trace Element and Mineral Bioavailability. J. Nutr. 133:2973S-7S.

Itah, Y., A. Powell, A., M. A. Beaumont et al. 2009. The origins of lactase persistence in Europe. PLoS Comput. Biol. 5, e1000491.

James, A. 1997. The ancient Celts: Discovery or Invention? British Museum Journal $28: 18-22$.

Jankauskas, R. and Z. Palubeckaité. 2006. Paleopathological review of the Zvejnieki sample: Analysis of cases and considerations of subsistence. In: Back to the Origin. New Research in the Mesolithic-Neolithic Zvejnieki Cemetery and Environment, Northern Latvia, L. Larsson and I. Zagorska, eds. Acta Archaeologica Lundensia Series, No 8, 149 Z 63. Stockholm: Almqvist and Wiksell.

Jazayeri, M., V. Bakayev, P. Adibi et al. 2003. Frequency of HFE gene mutations in 
Iranian beta-thalassaemia minor patients. Eur. J. Haematol. 71:408-411.

Jézéquel, P., M. Bargain, F. Lellouche et al. 1998. Allele frequencies of hereditary hemochromatosis gene mutations in a local population of west Brittany. Hum. Genet. 102:332-333.

Jouanolle, A. M., G. Gandon, P. Jézéquel et al. 1996. Haemochromatosis and HLA-H. Nat. Genet. 14:251-252.

Kaptijn, R., T. Thomese, T. G. van Tilburg et al. 2010. How grandparents matter: Support for the cooperative breeding hypothesis in a contemporary Dutch population. Hum. Nat. 21:393-405.

Karimi, M., M. Yavarian, P. Delbini et al. 2004. Spectrum and haplotypes of the HFE hemochromatosis gene in Iran: H63D in b-thalassemia major and the first E277K homozygous. Hematol. J. 5:524-527.

Kazemi-Shirazi L., C. Datz T., Maier-Dobersberger et al. 1999. The relation of iron status and hemochromatosis gene mutations in patients with chronic hepatitis $\mathrm{C}$. Gastroenterology116:127-34.

Kelly, T. M., C. Q. Edwards, A. W. Meikle et al. 1984. Hypogonadism in Hemochromatosis: Reversal with Iron Depletion. Ann. Intern. Med. 101:629632.

Kent, S. 1986. The influence of sedentism and aggregation on porotic hyperostosis and anemia: A case study. Man 21:605-636.

Khan K. S., D. Wojdyla, L. Say et al. 2006. WHO analyses of causes of maternal death: A systematic review. Lancet 367:1066-1074. 
Khondrashova, T. V., K. Neriishi, S. Ban et al. 2006. Frequency of hemochromatosis gene $(H F E)$ in Russian healthy women and patients with estrogen-dependent cancers. Biochim. Biophys. Acta.--Molecular Basis of Disease 1761:59-65.

Kindstedt, P. S. 2012. Cheese and Culture: A History of Cheese and its Place in Western Civilization. White River Junction, VT: Chelsea Green Publishing.

Klepinger, L. L. 1984. Nutritional assessment from bone. Annu. Rev. Anthropol. 13:7596.

Klitz, W., G. Thompson, N. Borat et al. 1992. Evolutionary and population perspectives of the human HLA complex. Evol. Biol. 26:35-72.

Kohlmeier, L., M. Mendez, S. Shalnova et al. 1998. Deficient iron intakes among women and children in Russia: Evidence from the Russian longitudinal monitoring survey. Am. J. Public Health 88:576-580.

Kolars, J. C., M. D. Leavitt, A. Mostafa et al. 1984. Yogurt- An autodigesting source of lactose. N. Engl. J. Med. 310:1-3.

Laland, K. N. and G. R. Brown. 2002. Sense and Nonsense: Evolutionary Perspectives on Human Behaviour. Oxford: Oxford University Press.

Laland, K. N. and G. R. Brown. 2006. Niche construction, human behavior, and the adaptive lag hypothesis. Evol. Anthropol. 15:95-104.

Legendre, P. 1993. Spatial autocorrelation: Trouble or new paradigm? Ecology 74:16591673.

Legge, A. J. 1981. Aspects of cattle husbandry. In: Farming Practice in British Prehistory, R. Mercer, ed. Edinburgh: Edinburgh University Press. 169-181. 
Legge, A. J. 2008. Livestock and Neolithic society at Hambledon Hill, Dorset, England. In Hambledon Hill, Dorset, England: Excavation and Survey of a Neolithic Monument Complex and its Surrounding Landscape. vol. 2. R. Mercer and F. Healey, eds. Swindon: English Heritage. 536-585.

Lewis, M. E. 2002. Impact of industrialization: Comparative study of child health in four sites from Medieval and Postmedieval England (A.D. 850-1859). Am. J. Phys. Anthrop. 119:211-223.

Lin, A., W. H. Yan, H. H. Xu et al. 2007. Analysis of the HFE gene (C282Y, H63D and S65C) mutations in a general Chinese Han population. Tissue Antigens 70:252255.

Little, M. A. and P. W. Leslie 1999 Turkana Herders of the Dry Savana: Ecology and Biobehavioral Response of Nomads to an Uncertain Environment. (Research Monographs in Human Population Biology). Oxford. Oxford University Press.

Livesey, K. J., V. L. C. Wimhurst, K. Carter et al. 2004. The 16189 variant of mitochondrial DNA occurs more frequently in C282Y homozygotes with haemochromatosis than those without iron loading. J. Med. Genet. 41:6-10.

Longo, F., G. Zecchina, L. Sbaiz et al. 1999. The influence of hemochromatosis mutations on iron overload of thalassemia major. Haematol. 84:799-800.

Loreal, O., Y. Deugnier, R. Moirand, et al. 1992. Liver fibrosis in genetic hemochromatosis. Respective roles of iron and non-iron related factors in 127 homozygous patients. J. Hepatol. 16:122-127.

McCracken, R. D. 1971. Lactase deficiency: An example of dietary evolution. Curr. Anthropol. 12:479-517. 
McCune, C. A., L. N. Al-jader, A May et al. 2002. Hereditary hemochromatosis: Only $1 \%$ of adult HFE C282Y homozygotes in South Wales have a clinical diagnosis of iron overload. Hum. Genet. 111:538-543.

McDonnell, S.M. and D. Witte. 1997. Hereditary hemochromatosis: Preventing chronic effects of this underdiagnosed disorder. Postgraduate Medicine 102:83-85, 88$91,94$.

Macfarlane, B. J., W. R. Bezwoda, T. H. Bothwell et al. 1988. Inhibitory effect of nuts on iron absorption. Am. J. Clin. Nutr. 47:270-274.

Maier, R. F., H. Witt, C. Bührer et al. 1999. HFE gene mutation and transferrin saturation in very low birthweight infants. Arch. Dis. Child. Fetal Neonatal Ed. 81:F144F145

Maruyama, T. 1974. The age of an allele in a finite population. Genet. Res. 23:137-143.

Meier, P., P. Schuff-Werner, and M. Steiner. 2005. Hemochromatosis gene HFE Cys282Tyr mutation analysis in a cohort of Northeast German hospitalized patients supports assumption of a North to South allele frequency gradient throughout Germany. Clin. Lab. 51:539-543.

Meiklejohn, C. and J. Babb. 2011. Long bone length, stature and time in the European Late Pleistocene and Early Holocene. In Human Bioarchaeology of the Transition to Agriculture, R. Pinhasi and J. T. Stock, eds. Singapore. WileyBlackwell. 153-175.

Mercier, G., C. Bathelier, and G. Lucotte. 1998. Frequency of the C282Y mutation of hemochromatosis in five French populations. Blood Cells Mol. Dis. 24:165-166. 
Merryweather-Clarke, A. T., J. J. Pointon, J. D. Shearman et al. 1997. Global prevalence of putative haemochromatosis mutations. J. Med. Genet. 34:275-278.

Merryweather-Clarke, A. T., J. J. Pointon, A. M. Jouanelle et al. 2000. Geography of HFE C282Y and H63D mutations. Genet. Test. 4:183-198.

Merryweather-Clarke, A. T., H. Simonson, J. D. Shearman et al. 1999. A retrospective anonymous pilot study in screening newborns for $H F E$ mutations in Scandinavian populations. Hum. Mutat. 13:154-159.

Merryweather-Clarke, A. T., E. Cadet, A. Bomford et al. 2003. Digenic inheritance of mutations in HAMP and HFE results in different types of hemochromatosis. Hum. Mol. Genet. 12:2241-2247.

Miedzybrodzka, Z., S. Loughlin, D. Baty et al. 1999. Haemochromatosis mutations in North-East Scotland. Br. J. Haematol. 106:385-387.

Mikhailova, S. V., V. F. Kobzev, I. V. Kulikov et al. 2003. Polymorphism of the HFE gene associated with hereditary hemochromatosis in populations off Russia. Russian Journal of Human Genetics 39:828-835.

Mikkelsaar, A.-V., L. Beckman, G. Tasa et al. 1999. Regional differences of hemochromatosis mutations in Estonian populations. Eur. J. Hum. Genet. 7(Suppl 1):P-595.

Milman, N. and P. Pedersen. 2003. Evidence that the Cys282Tyr mutation of the HFE gene originated from a population in Southern Scandinavia and spread with the Vikings. Clin. Genet. 64:36-47. 
Milman, N., P. Pedersen, L. Ovesen et al. 2004. Frequency of the C282Y and H63D mutations of the hemochromatosis gene (HFE) in 2501 ethnic Danes. Ann. Hematol. 83:654-657.

Miritoiu, N. 1992. Porotic hyperostosis in a Free Dacians' necropolis at Poisnesti (Vaslui County): Congenital hemolytic anemia or iron deficiency anemia? Preliminary considerations. Annuaire Roumain d'Anthropologie 29:3-12.

Moczulski, D. K., W. Grzeszczak, and B. Gawlik. 2001. Frequency of the hemochromatosis C282Y and H63D mutations in a Polish population of Slavic origin. Med. Sci. Monit. 7:441-443.

Moirand, R., A. M. Jouanolle, P. Brissot et al. 1999. Phenotypic expression of HFE mutations: A French study of 1110 unrelated iron-overload patients and relatives. Gastroenterology 116:372-377.

Molleson, T. and M. Cox. 1993. The Spitalfields Project: Volume 2 - The Anthropology. The Middling Sort. Council for British Archaeology Report, 86.

Motulsky, A. G. 1979. Genetics of hemochromatosis. N. Engl. J. Med. 301:1291.

Mullighan, C. G., M. Bunce, M.. G. C. Fanning et al. 1998. A rapid method of haplotyping $H F E$ mutations and linkage disequilibrium in a Caucasoid population. Gut 42(4): 566-569.

Mura, C., O. Roguenes, C. Ferec et al. 1999. HFE mutation analysis in 711 hemochromatosis probands: Evidence for S65C implication in mild form of hemochromatosis. Blood 93:2502-2505. 
Murphy, S., M. D. Curran, N. McDougall et al. 1998. High incidence of the Cys 282 Tyr mutation in the HFE gene in the Irish population-implications for haemochromatosis. Tissue Antigens 52:484-488.

Naugler, C. 2008. Hemochromatosis: A Neolithic adaptation to cereal grain diets. Med. Hypotheses 70:691-692.

Niederau, C., R. Fischer, A. Purschel et al. 1996. Long-term survival in patients with hereditary hemochromatosis. Gastroenterology 110:1107-1119.

Niederau, C., R. Fischer, A. Sonnenberg et al. 1985. Survival and causes of death in cirrhotic and in noncirrhotic patients with primary hemochromatosis. N. Engl. J. Med. 313:1256-1262.

Nielsen, P., A. Carpinteiro, R. Fischer et al. 1998. Prevalence of the C282Y and H63D mutations in the HFE gene in patients with hereditary haemochromatosis and in control subjects from Northern Germany. Br. J. Haematol. 103:842-845.

Papanikolaou, G., M. Politou, E. Terpos et al. 2000. Hereditary hemochromatosis: HFE mutation analysis in Greeks reveals genetic heterogeneity. Blood Cells Mol. Dis. 26:163-168.

Papazoglou D., T. Exiara, M. Speletas et al. 2003. Prevalence of Hemochromatosis Gene (HFE) Mutations in Greece. Acta. Haematol. 109:137-140.

Parkkila, S., O. Niemelä, E.-R. Savolainen et al. 2001. HFE mutations do not account for transfusional iron overload in patients with acute myeloid leukemia. Transfusion 41: $828-831$.

Papathanasiou, A. 2003. Stable isotope analysis in Neolithic Greece and possible implications on human health. Intl. J. Osteoarchaeol. 13:314-324. 
Papathanasiou, A. 2005. Health status of the Neolithic population of Alepotrypa Cave, Greece. Am. J. Phys. Anthrop. 126:377-390.

Pärlist, P., A.-V. Mikelsaar, G. Tasa et al. 2001. The frequency of C282Y and H63D mutations in Hemochromatosis gene in native Estonians. Eur. J. Epidemiol. $17: 213-216$.

Pedersen, P., G. V. Melsen, and N. Milman. 2008. Frequencies of the haemochromatosis gene (HFE) variants C282Y, H63D and S65C in 6,020 ethnic Danish men. Ann. Hematol. 87:735-740.

Pelucchi, S., R. Mariani, S. Calza et al. 2012. CYBRD1 as a modifier gene that modulates iron phenotype in HFE p.C282Y homozygous patients. Hematologica $97: 1818-1825$.

Pennington, J. A., D. B. Wilson, B. E. Young et al. 1987. Mineral content of market samples of whole milk. J. Am. Diet. Assoc. 87:1036-1042.

Perry, G. H., N. J. Dominy, K. G. Claw et al. 2007. Diet and the evolution of the human amylase gene copy number variation. Nat. Genet. . 39:1256-1260.

Pietrangelo A. 2004. Hereditary hemochromatosis: A new look at an old disease. N. Engl. J. Med. 350:2383-2397.

Piperno, A., C. Arosio, S. Fargion et al. 1996. The ancestral hemochromatosis haplotype is associated with a severe phenotype expression in Italian patients. Hepatology $24: 43-46$.

Piperno, A., M. Sampietro, A. Pietrangelo et al. 1998. Heterogeneity of hemochromatosis in Italy. Gastroenterology 114:996-1002.

Pointon, J. J., V. Viprakasit, K. L Miles et al. 2003. Hemochromatosis gene (HFE) 
mutations in South East Asia: a potential for iron overload. Blood Cells, Mol. Dis. 30:302-306.

Potekhina, E. S., A. V. Lavrov, L. M. Samokhodskaya et al. 2005. Unique genetic profile of hereditary hemochromatosis in Russians: High frequency of C282Y mutation in population, but not in patients. Blood Cells Mol. Dis. 35:182-188.

Pozzato, G., F. Zorat, F. Nascimben et al. 2001. Haemochromatosis gene mutations in a clustered Italian population: evidence of high prevalence in people of Celtic ancestry. Eur. J. Hum. Genet. 9:445-451.

Price, T. D. 2000. The introduction of farming to northern Europe. In: Europe's First Farmers, T. D. Price, ed. Cambridge: Cambridge University Press. 260-300.

Prom-U-Thai, C., L. Huang, R. P. Glahn et al. 2006. Iron (Fe) bioavailability and the distribution of anti-Fe nutrition biochemicals in the unpolished, polished grain and bran fraction of five rice genotypes. J. Sci. Food Agric. 86:1209-1215.

Racchi, O., R. Mangerini, D. Rapezzi et al. 1999. Mutations of the HFE Gene and the Risk of Hepatocellular Carcinoma. Blood Cells Mol. Dis. 25:350-353.

Raddatz ., T. Legler, R. Lynen et al. 2003. HFE-genotyp und Eisenstoffwechselparameter bei Erstblutspendern: Eine C282Y-Heterozygotie geht mit einer Erhöhten Transferrinsättigung einher. Z. Gastroenterol. 41:1069-1076.

Raha-Chowdhury, R. and J. R. Gruen. 2000. Localization, allelic heterogeneity, and origins of the hemochromatosis gene. In: Hemochromatosis, J. Barton and C. Q. Edwards, eds. Cambridge: Cambridge University Press. 74-90. 
Raszeja-Wyszomirska, J., G. Kurzawski, J. Suchy, et al. 2008. Frequency of mutations related to hereditary haemochromatosis in northwestern Poland. J. Appl. Genet. 49(1):105-107.

Rathbun, T. A. 1984 Skeletal pathology from the Paleolithic through the Metal Ages in Iran and Iraq. In: Paleopathology at the Origins of Agriculture, M. N. Cohen and G. J. Armelagos, eds. Orlando, FL: Academic Press. 137-167.

Reish, O., N. Shefer-Kaufmann, D. C. Shimshoni et al. 2010. Frequencies of C282Y and H63D alleles in the HFE gene among various Jewish ethnic groups in Israel: A change of concept required. Genet. Med. 12:122-125.

Restagno, G., A. M. Gómez, L. Sbaiz et al. 2000. A pilot C282Y hemochromatosis screening in Italian newborns bt TaqMan technology. Genet. Test. 4:177-181.

Richards, M. T., D. Price, and E. Koch. 2003. Mesolithic and Neolithic subsistence in Denmark: New stable isotope data. Curr. Anthropol. 44:288-295.

Richards, M. T., R. Jacobi, J. Cook et al 2005 Isotope evidence for the intensive use of marine foods by Late Upper Paleolithic humans. J. Hum. Evol. 49:390-394.

Roberts, C. and M. Cox. 2003. Health and Disease in Britain from Prehistory to the Present Day. Stroud. Sutton Publishing Company.

Rochette, J., J. J. Pointon, C. A. Fisher et al. 1999. Multicentric origin of hemochromatosis gene (HFE) mutations. Am. J. Hum. Genet. 64:1056-1062.

Roe, M. A., A.-L. M. Heath, S. L. Oyston et al. 2005. Iron absorption in male C282Y heterozygotes. Am. J. Clin. Nutr. 81:814-821. 
Rossi, E., M. K. Bulsara, J. K. Olynyk et al. 2001. effects of hemochromatosis genotype and lifestyle factors on iron and red cell indices in a community population. Clin. Chem. 47:202-208.

Rossi, E., J. K. Olynyk, D. J. Cullen et al 2000 Compound heterozygous hemochromatosis genotype predicts increased iron and erythrocyte indices in women. Clin. Chem. 46:162-166.

Rotter, J. I and J. M. Diamond. 1987. What maintains the frequencies of human genetic diseases? Nature 329:289-290.

Rowley-Conway, P. 2011. Westward Ho! The spread of agriculture from Central Europe to the Atlantic. Curr. Anthropol. 52(Supplenent 4):S431-S451.

Roychoudhury, A.K. and M. Nei. 1988. Human Polymorphic Genes: World Distribution. Oxford: Oxford U. Press.

Ruff, C. B. 2002. Variation in human body size and shape. Annu. Rev. Anthropol. $31: 211-232$.

Ryan, E., C. O'Keane and J. Crowe. 1998. Hemochromatosis in Ireland and HFE. Blood Cells Mol. Dis. 24:428-432.

Salter-Cid, L A, Y. Brunmark, D. Li et al. 1998. Transferrin receptor is negatively modulated by the hempchromatosis protein HFE: Implications for cellular iron homeostasis. Proc. Natl. Acad. Sci., U. S. A. 96:5434-5439.

Salvioni A., R. Mariani, C. Oberkanins et al. 2003. Prevalence of C282Y and E168X HFE mutations in an Italian population of Northern European ancestry. Haematology 88:250-255.

Sassi, R., S. Hmida, H. Kaabi et al. 2004. Prevalence of C282Y and H63D mutations in 
the haemochromatosis (HFE) gene in Tunisian population. Annales Génétique $47: 325-330$.

Schibler, J. 2006. The economy and environment of the $4^{\text {th }}$ and $3^{\text {rd }}$ millennia BC in the Northern Alpine foreland based on studies of animal bones. Environmental Archaeology 11:49-64.

Scholl T. O. 2005. Iron status during pregnancy: Setting the stage for mother and infant. Am. J. Clin. Nutr. 81:12185-12225.

Schulting, R. J. and M. P. Richards. 2002. The wet, the wild and the domesticated: The Mesolithic-Neolithic transition on the west coast of Scotland. European Journal of Archaeology 5:147-189.

Scotet, V., M.-C. Mérour, A.Y. Mercier et al. 2003. Hereditary hemochromatosis: Effect of excessive alcohol consumption on disease expression in patients homozygous for the C282Y mutation. Am. J. Epidemiol. 158:129-134.

Sherratt, A. 1981. Plough and pastoralism: Aspects of the secondary products revolution. In Patterns of the Past, I. Hodder, G. Isaacs, and N. Hammond, eds. Cambridge: Cambridge University Press. 261-305.

Simonsen, K., K. Dissing, L. Rudbeck et al. 1999. Rapid and simple determination of hereditary haemochromatosis mutations by multiplex PCR-SSCP: detection of a new polymorphic mutation. Ann. Hum. Genet. 63:193-197.

Soberl, L. and P. Evershed. 2009. Organic residue analysis of pottery from Warren Field Timber Hall and the Crathes Castle Overflow Car Park Site. In A Tale of the Unknown Unknowns: A Mesolithic Pit Alignment and a Neolithic Timber Hall at 
Warren Field, Crathers, Aberdeenshire. H. K. Murray, J. C. Murray, and S. M. Fraser, eds. Oxford: Oxbow. Pp. 93-97.

Sohda, T., J. Yanai, H. Soejima et al. 1999. Frequencies in the Japanese population of HFE gene mutations. Biochem. Genet. 37:63-68.

Sokal, R. R., N. L. Oden, and C. G. Wilson. 1991. Genetic evidence for spread of agriculture in Europe by demic diffusion. Nature 351:143-145.

Spangenberg, J. E., S. Jacomet, and J. Schibler. 2006. Chemical analyses of organic residues in archaeological pottery from Arbon 3, Switzerland - evidence for dairying in the Late Neolithic. J. Archaeol. Sci. 33:1-13.

Steckel, R. H., J. C. Rose, C. S. Larsen et al. 2002. Skeletal health in the Western Hemisphere from $4000 \mathrm{BC}$ to the present. Evol. Anthropol. 11:142-155.

Steffensen, R., K. Varming, and C. Jersild. 1998. Determination of gene frequencies for two common haemochromatosis mutations in the Danish population by a novel polymerase chin reaction with sequence specific primers. Tissue Antigens $52: 230-235$.

Stiner, M. C., N. D. Munro, and T. A. Surovell. 2000. The tortoise and the hare: Smallgame use, the broad-spectrum revolution and Paleolithic demography. Curr. Anth. 41:39-73.

Straus, L. G. 1977. Of deerslayers and mountain men: Paleolithic faunal exploitation in Cantabrian Spain. In For Theory Building in Archaeology: Essays on Faunal Remains, Aquatic Resources, Spatial Analysis, and Systemic Modeling, L. R. Binford, ed. New York: Academic Press. 41-76. 
Stuart-Macadam, P. 1989. Porotic hyperostosis: Representative of a childhood condition. Am. J. Phys. Anthropol. 66:391-398.

Stuart-Macadam, P. 1991. Anaemia in Roman Britain: Poundbury Camp. In Health in Past Societies: Biocultural Interpretations of Human Skeletal Remains in Archaeological Contexts, H. Bush and M. Zvelebil, eds. British Archaeological Reports, International Series., A67.

Stuart-Macadam, P. 1998. Iron deficiency anemia: Exploring the difference. In Sex and gender in Paleopathological Perspective. A. L. Grauer and P. Stuart-Macadam, eds. Cambridge: Cambridge University Press. 45-63.

Szakony S., I. Balogh, and L. Muszbek. 1999. The frequency of the haemochromatosis C282Y mutation in the ethnic Hungarian and Romany populations of eastern Hungary. Br. J. Haematol. 107:464-5.

Thomas, J. 2003. Thoughts on the "repackaged" Neolithic Revolution. Antiquity 77:6774.

Thomas, W., A. Fullan, D. B. Loeb et al. 1998. A haplotype and linkage disequilibrium analysis of the hereditary hemochromatosis gene region. Hum. Genet. 102:517525.

Toomajian, C., R. S. Ajioka, L. B. Jorde et al. 2003. A method for detecting recent selection in the human genome from allele age estimates. Genetics 165: 287297.

Toomajian, C. and M. Kreitman 2002 Sequence variation and haplotype structure at the human HFE locus. Genetics. 161:1609-1623. 
Tordai A., H. Andrikovics, L. Kalmár et al. 1998. High frequency of the haemochromatosis C282Y mutation in Hungary could argue against a Celtic origin of the mutation. J. Med. Genet. 35:878-879.

Tuomainen T. P., K. Kontula, K. Nyyssönen et al. 1999. Increased risk of acute myocardial infarction in carriers of the hemochromatosis gene Cys282Tyr mutation : a prospective cohort study in men in eastern Finland. Circulation 100:1274-1279.

U. S. Department of Agriculture, Agricultural Research Service. 2012. USDA National Nutrient Database for Standard Reference, Release 25. Nutrient Data Laboratory Home Page, http://www.ars.usda.gov/ba/bhnrc/ndl

Van Aken, M.O., A.J.M. de Craen, J. Gussekloo et al. 2002. No increase in mortality and morbidity among carriers of the C282Y mutation of the hereditary haemochromatosis gene in the oldest old: the Leiden 85-plus Study. Eur. J. Clin. Invest. 32:750-754.

Velati, C., E. Marlianici, D. Rigamonti et al. 2003. Mutations of the hemochromatosis gene in Italian candidate blood donors with increased transferrin saturation. Hematol. J. 4:436-440.

Voight, B. F., S. Kudaravalli, X. Wen et al. 2006. A map of recent positive selection in the human genome. PLoS Biology 4, no. 3, e72.

Waalen, J., V. Felitti, T. Gelbart et al. 2002. Penetrance of hemochromatosis. Blood Cells Mol. Dis. 29:418-432.

Wang, E. T., G. Kodama, P. Baldi et al. 2006. Global landscape of recent inferred Darwinian selection for Homo sapiens. Proc. Natl. Acad. Sci. 103:135-140. 
Weinberg, R. B. 1999. Apolipoprotein A-IV-2 allele: Association of its world-wide distribution with adult persistence of lactase and speculation on its function and origin. Genet. Epidemiol.17:285-297.

Wells, C. 1982. The human burials, In: Cirencester Excavations II: Romano-British Cemeteries at Cirencester. A. McWhirr, L. Viner and C. Wells, eds. Cirencester: Cirencester Excavation Committee, Corinium Museum. 135-202.

Wells, P. S. 1984. Farms, Villages, and Cities: Commerce and Urban Origins in Late Prehistoric Europe. Ithaca: Cornell University Press.

Wells, P. S. 2008. Barbarians to Angels: The Dark Ages Reconsidered. New York: W. W. Norton \& Company.

Whittington, C. A. 2006. Was the C282Y mutation an Irish Gaelic mutation that the Vikings help disseminate? Med. Hypotheses 67:1270-1273.

Whittle, A. 1996. Europe in the Neolithic. The Creation of New Worlds. Cambridge: Cambridge University Press.

Williamson, S. H., M. J. Hubisz, A. G. Clark et al. 2007. Localizing recent adaptive evolution in the human genome. PLoS Genet. 3(6)ie90.

Willis, G., B. A. Jennings, E. Goodman et al. 1997. A High Prevalence of HLA-H 845A Mutations in Hemochromatosis Patients and the Normal Population in Eastern England. Blood Cells Mol. Dis. 23:288-291.

Wittwer-Backofen, U. and N. Tomo. 2008. From health to civilization stress? In search for traces of a health transition during the Early Neolithic in Europe. In The Neolithic Demographic Transition and its Consequences, J.-P. Bocquet-Appel and O. Bar-Josef, eds. Springer. 501-538. 
World Health Organization. 2008. Worldwide prevalence of anaemia 1993-2005.

Geneva: World Health Organization.

Yönal, O., Ö. Hatirnaz, F. Akyüz et al. 2007. HFE gene mutation, chronic liver disease, and iron overload in Turkey. Dig. Dis. Sci. 52:3298-3302.

Zdárský E., J. Horák, J. Stríteský et al. 1999. [Hemochromatosis. Determination of the C282Y mutation frequency in the population of the Czech Republic and sensitivity of hemochromatosis detection using Guthrie cards]. Cas. Lek. Cesk. 138:497-499. [Article in Czech]

Zimmermann, M. B. and R. F. Hurrell. 2007. Nutritional iron deficiency. Lancet 370:511-520.

Zorai, A., C. L. Harteveld, R. Rachdi et al. 2003. Frequency and spectrum of hemochromatosis mutations in Tunisia. Hematol. J. 4:433-435.

Zvelebil, M. and M. Lillie. 2000. Transition to agriculture in eastern Europe. In Europe's First Farmers, T. D. Price, ed. Cambridge: Cambridge University Press. 57-92. 
Table 1. List of samples along with sample sizes, allele frequencies (\%) and references for the HFE (C282Y) allele used in the analysis.

\begin{tabular}{|c|c|c|c|}
\hline Population & \begin{tabular}{|l} 
Sample \\
Size
\end{tabular} & $\begin{array}{l}\text { C282Y } \\
\text { Allele } \\
\text { Frequency }\end{array}$ & Reference \\
\hline England, Northeast & 117 & 7.7 & Grove et al 1998 \\
\hline $\begin{array}{l}\text { England, } \\
\text { Birmingham }\end{array}$ & 368 & 6 & Merryweather-Clark et al 1997 \\
\hline $\begin{array}{l}\text { England, } \\
\text { East Anglia, } \\
\text { Norwich }\end{array}$ & 200 & 8.5 & Willis et al 1997 \\
\hline England, Oxford & 330 & 10 & Mullighan et al 1998 \\
\hline $\begin{array}{l}\text { Northeast Scotland, } \\
\text { Aberdeen }\end{array}$ & 188 & 1.4 & $\begin{array}{l}\text { Merryweather-Clarke etal } 2000 \\
\text { Miedzybrodzka et al } 1999\end{array}$ \\
\hline Northern Ireland & 404 & 9.9 & Murphy et al 1998 \\
\hline Orkney Islands & 103 & 4.9 & Merryweather-Clarke et al 2000 \\
\hline Ireland & 45 & 10 & Merryweather-Clarke et al 1997 \\
\hline Ireland & 150 & 6 & Merryweather-Clarke et al 1997 \\
\hline Ireland & 800 & 11.4 & Merryweather-Clarke et al 2000 \\
\hline Ireland & 1119 & 10.1 & Merryweather-Clarke et al 2000 \\
\hline Ireland, Dublin & 109 & 14 & Ryan et al 1998 \\
\hline Ireland, Dublin & 411 & 10.9 & Byrnes et al 1999, in Byrnes 2001 \\
\hline Ireland, Dublin & 100 & 10.4 & Byrnes et al 2001 \\
\hline
\end{tabular}




\begin{tabular}{|c|c|c|c|}
\hline Finns, Jyvaskyla & 38 & 0 & Merryweather-Clarke et al 1997 \\
\hline Finland, Kuopio & 1361 & 3.4 & Tuomainen et al. 1999 \\
\hline Finland, North & 173 & 5.2 & Beckman et al. 1997 \\
\hline Finland, Oulu & 128 & 5.1 & Parkkila et al 2001 \\
\hline Denmark & 876 & 5.6 & Pedersen et al 2008 \\
\hline Denmark, Aalborg & 200 & 6.8 & Steffensen et al 1998 \\
\hline Denmark, Aalborg & 219 & 8.2 & Merryweather-Clark et al 1999 \\
\hline $\begin{array}{l}\text { Denmark, } \\
\text { København }\end{array}$ & 37 & 9.5 & Merryweather-Clark et al 1997 \\
\hline $\begin{array}{l}\text { Denmark, } \\
\text { Kobenhavn }\end{array}$ & 420 & 6.2 & Simonsen et al 1999 \\
\hline $\begin{array}{l}\text { Denmark, } \\
\text { København }\end{array}$ & 9174 & 5.6 & Ellervik et al 2001 \\
\hline $\begin{array}{l}\text { Denmark, } \\
\text { Kobenhavn }\end{array}$ & 1889 & 5.7 & Milman et al 2005 \\
\hline Sweden & 358 & 5.2 & Merryweather-Clarke et al 2000 \\
\hline Sweden, Stockholm & 117 & 3.8 & Cardoso et al 1998 \\
\hline Sweden, Umea & 206 & 7.5 & Beckman et al 1997 \\
\hline Swedish Saami & 151 & 2 & Beckmann et al 2001 \\
\hline Germany, Bremen & 53 & 1.9 & Merryweather-Clark et al 1997 \\
\hline Germany, Hsmburg & 157 & 4.8 & Nielsen et al 1998 \\
\hline Germany, Frankfurt & 153 & 2.6 & Gottschalk et al 1998 \\
\hline Germany, Frankfurt & 251 & 3.6 & Gottschalk et al 2000 \\
\hline
\end{tabular}




\begin{tabular}{|l|r|r|l|}
\hline Germany, Cologne & 250 & 3.2 & Höhler et al 2000 \\
\hline Germany, Göttingen & 500 & 4.6 & Raddatz et al 2003 \\
\hline Germany, Central & 126 & 2.4 & Hellerbrand et al 2001 \\
\hline Germany, East & 425 & 3.8 & Merryweather-Clarke et al 2000 \\
\hline Germany, East & 115 & 4 & Merryweather-Clarke et al 1997 \\
\hline Germany, Bavaria & 62 & 5.6 & Merryweather-Clarke et al 1997 \\
\hline Germany, & 180 & 7.2 & Braun et al 1998 \\
\hline Regensburg & & & \\
\hline Austria, Salzburg & 271 & 4.1 & Datz et al 1997 \\
\hline Austria & 487 & 4.8 & Kazemi-Shirazi et al 1999 \\
\hline Czech Republic & 139 & 5 & Zdarsky et al 1999 \\
\hline Czech Republic & 100 & 4.5 & Hrachovinova et al 1999 \\
\hline Czech Republic, & 254 & 3.9 & Cimburova et al 2002 \\
Prague & & & \\
\hline Hungary & 277 & 5.6 & Tordai et al 1998 \\
\hline Hungary, East & 304 & 2.6 & Raszeja-Szakony et al 1999 \\
\hline Hungary, Budapest & 994 & 3.4 & Andrikovics et al 1999 \\
\hline Poland, North & 117 & 4.7 & Wyszomirska et al 2008 \\
\hline Poland, Central & 871 & 3.1 & Moczulski et al 2001 \\
\hline Roma, Slovakia & 367 & 4.9 & Gabriková et al 2012 \\
\hline Roma, Hungary & 140 & 1.1 & Szakony et al 1999 \\
\hline Russia, Moscow & 850 & & \\
\hline
\end{tabular}




\begin{tabular}{|l|r|r|l|}
\hline Russia, Novosibirsk & 150 & 3.7 & Mikhailova et al 2003 \\
\hline Russia, Obninsk & 260 & 3.3 & Khondrashova et al 2006 \\
\hline Russia, Udmurts & 46 & 0 & Merryweather-Clark et al 1997 \\
\hline Russia, Mansis & 43 & 0 & Mikhailova et al 2003 \\
\hline Russia, Khantys & 53 & 0 & Mikhailova et al 2003 \\
\hline Ashkenazim & 381 & 1.4 & Reish et al 2010 \\
\hline Tunisia, Tunis \& & 97 & 0.5 & Zorai et al 2003 \\
\hline Nabeul & & & \\
\hline Tunisia, Tunis & 570 & 0.1 & Sassi et al 2004 \\
\hline Iran, Hormozgan & 294 & 0 & Karimi et al 2004 \\
\hline Iran Fars (Shiraz) & 506 & 0 & Karimi et al 2004 \\
\hline Iran, Tehran & 104 & 9 & Jazayeri et al 2003 \\
\hline France, Paris & 126 & 4 & Mercier et al 1998b \\
\hline France, Amiens & 991 & 5 & Merryweather-Clarke et al 2000 \\
\hline France, Toulouse & 95 & 4.2 & Borot et al 1997 \\
\hline France, South & 60 & 3.3 & Aguilar Martinez et al 1997 \\
\hline France, Catalans & 166 & 2.1 & Mercier et al 1998a \\
\hline France, Brittany & 62 & 5.6 & Mercier et al 1998a \\
\hline France, Brittany & 410 & 7.7 & Mura et al 1999 \\
\hline France, Brittany & 139 & 2.9 & Moirand et al 1999 \\
\hline France, Brest & 7000 & 7.8 & Merryweather-Clarke et al 2000 \\
\hline France, Rennes & 1000 & 6.5 & Jouanolle et al 1998 \\
\hline
\end{tabular}




\begin{tabular}{|c|c|c|c|}
\hline France, West & 254 & 9.4 & Jézéquel et al 1998 \\
\hline Italy, Naples & 91 & 0.5 & Merryweather-Clark et al 1997 \\
\hline Italy, Rome & 139 & 1.1 & Piperno et al 1998 \\
\hline Italy, South & 458 & 1.7 & Restagno et al 2000 \\
\hline Italy, South & 100 & 0 & Campo et al 2001 \\
\hline Sardinia & 61 & 0.5 & Candore et al 2002 \\
\hline Sicily & 106 & 0 & Candore et al 2002 \\
\hline Italy & 1331 & 2.1 & Restagno et al 2000 \\
\hline Italy, Brescia & 114 & 1.8 & Costarelli et al 2007 \\
\hline Italy, Piemonte & 104 & 4.8 & Candore et al 2002 \\
\hline Italy, Piemonte & 189 & 1.1 & Longo et al 1999 \\
\hline Italy, North & 50 & 1 & Carella et al 1997 \\
\hline Italy, Torino & 310 & 2.7 & Restagno et al 2000 \\
\hline Italy, Northeast & 131 & 2.3 & Borgna-Pignatti et al 1998 \\
\hline Italy, Friuli & 100 & 6 & Candore et al 2002 \\
\hline $\begin{array}{l}\text { Italy, Emilia } \\
\text { Romagna }\end{array}$ & 207 & 1.7 & Candore et al 2002 \\
\hline $\begin{array}{l}\text { Italy, Cimbri } \\
\text { (Verona) }\end{array}$ & 149 & 4.8 & Pozzato et al 2001 \\
\hline Italy, Genoa & 130 & 4.2 & Racchi et al 1999 \\
\hline Italy, Milan & 128 & 0.8 & Sampietro et al 1998 \\
\hline Italy, Milan & 139 & 1.1 & Piperno et al 1998 \\
\hline
\end{tabular}




\begin{tabular}{|l|r|r|l|}
\hline Italy, Modena & 2100 & 1.6 & Cassanelli et al 2001 \\
\hline Italy, Modena & 149 & 3.4 & Pozzato et al 2001 \\
\hline Italy, Monza & 606 & 4.7 & Salvioni et al 2003 \\
\hline Greece & 139 & 1.4 & Merryweather-Clark et al 1997 \\
\hline Greece & 158 & 0.3 & Papanikolaou et al 2000 \\
\hline Greece & 196 & 0.9 & Papanikolaou et al 2000 \\
\hline Greece, & 264 & 0 & Papazoglou et al 2003 \\
\hline Alexandropoli & & & \\
\hline Greece, Cyprus & 57 & 0 & Merryweather-Clark et al 1997 \\
\hline Turkey & 31 & 0 & Merryweather-Clark et al 1997 \\
\hline Turkey, Istanbul & 158 & 0 & Barut et al 2003 \\
\hline Turkey, Istanbul & 138 & 0.7 & Yönal et al 2007 \\
\hline Turkey, Cyprus & 39 & 0 & Merryweather-Clark et al 1997 \\
\hline Estonia, West & 158 & 5.1 & Mikelsaar et al 1999 \\
\hline Estonia, Southeast & 92 & 4.3 & Mikelsaar et al 1999; Pärlist et al \\
\hline Estonia, Saaremaa & 96 & 2.1 & Mikelsaar et al 1999; Pärlist et al \\
\hline Estonia, Hiiumaa & 96 & 1.6 & Mikelsaar et al 1999; Pärlist et al \\
\hline Estonia, Hiiumaa & 442 & 3.5 & Mikelsaar et al 1999 \\
\hline Basques, France, & 92 & 1.6 & Mercier et al 1998a \\
\hline Biarritz & & & \\
\hline Basque, Spain & & & \\
\hline Basque, Spain & & & \\
\hline
\end{tabular}




\begin{tabular}{|l|r|r|l|}
\hline North India & 275 & 0 & Gurjeewan et al 2005 \\
\hline Japan, Fukuoka & 252 & 0 & Sohda et al 1999 \\
\hline Taiwan, Taipei & 596 & 0.3 & Chang et al 1997 \\
\hline China, Linhai & 395 & 0 & Lin et al 2007 \\
\hline
\end{tabular}

Table 2. Samples used in the regression analysis - The $\mathrm{C} 282 \mathrm{Y}$ values and the corresponding Lactase Persistence values. Statistical software used to analyze was StatPlusMac 2009, Build 5.8.3.8.

\begin{tabular}{|c|c|c|c|c|}
\hline Population & $\begin{array}{l}\text { Number } \\
\text { of Studies }\end{array}$ & $\begin{array}{l}\text { Sample } \\
\text { Number }\end{array}$ & $\begin{array}{l}\mathrm{C} 282 \mathrm{Y} \\
\text { Frequency (\%) }\end{array}$ & $\begin{array}{l}\text { Lactase } \\
\text { Persistence } \\
(\%)\end{array}$ \\
\hline England & 4 & 1015 & 8 & 95 \\
\hline Scotland & 2 & 1197 & 10.6 & 95 \\
\hline Northern Ireland & 1 & 404 & 9.9 & 100 \\
\hline Ireland & 7 & 3636 & 10.5 & 96 \\
\hline Orkney Islands & 1 & 103 & 4.9 & 90 \\
\hline Finland & 5 & 1700 & 3.6 & 84 \\
\hline Denmark & 8 & 18835 & 5.7 & 96 \\
\hline Sweden & 4 & 931 & 5.8 & 93 \\
\hline Saami & 1 & 151 & 2 & 31 \\
\hline North Germany & 3 & 919 & 4.7 & 91 \\
\hline Central Germany & 5 & 1280 & 3.7 & 86 \\
\hline East Germany & 2 & 540 & 3.8 & 78 \\
\hline
\end{tabular}




\begin{tabular}{|c|c|c|c|c|}
\hline Bavaria & 2 & 242 & 6.8 & 86 \\
\hline Austria & 2 & 758 & 4.5 & 81 \\
\hline Czech Republic & 3 & 493 & 4.3 & 82 \\
\hline Hungary & 3 & 1575 & 3.6 & 63 \\
\hline North Poland & 1 & 117 & 4.7 & 71 \\
\hline Central Poland & 1 & 871 & 3.1 & 63 \\
\hline Roma & 2 & 507 & 3.9 & 44 \\
\hline Russia, Russians & 3 & 1260 & 3.5 & 42 \\
\hline Russia, Udmurts & 1 & 46 & 0 & 41 \\
\hline Russia, Mansis & 1 & 43 & 0 & 28 \\
\hline Russia, Khantys & 1 & 53 & 0 & 29 \\
\hline Ashkenazim & 3 & 381 & 1.4 & 16 \\
\hline Tunisia & 2 & 667 & 0.2 & 16 \\
\hline Iran & 3 & 904 & 0 & 14 \\
\hline North France & 2 & 1117 & 4.9 & 78 \\
\hline South France & 3 & 321 & 2.9 & 43 \\
\hline France, Brittany & 6 & 8865 & 7.6 & 78 \\
\hline South Italy & 7 & 3112 & 1.5 & 52 \\
\hline Sardinia & 1 & 61 & 0.5 & 14 \\
\hline Sicily & 1 & 106 & 0 & 29 \\
\hline North Italy & 17 & 8614 & 3.1 & 49 \\
\hline Greece & 5 & 814 & 0.5 & 13 \\
\hline
\end{tabular}




\begin{tabular}{|l|r|r|r|r|}
\hline Turkey & 4 & 366 & 0.3 & 31 \\
\hline Estonia & 4 & 442 & 3.5 & 50 \\
\hline Basques & 3 & 171 & 1.5 & 89 \\
\hline North India & 1 & 275 & 0 & 55 \\
\hline Thailand & 1 & 154 & 0 & 28 \\
\hline Japan & 1 & 252 & 0 & 12 \\
\hline Taiwan & 1 & 596 & 0.3 & 8 \\
\hline China & 1 & 395 & 0 & 28 \\
\hline
\end{tabular}


Table 3. Correlations of HFE allele C282Y and Lactase Persistence partialled by 19 other loci for which there are at least 16 comparable samples. Chromosome loci from OMIM; Table numbers from Roychoudhury and Nei (1988).

\begin{tabular}{|l|l|l|l|l|l|l|l|}
\hline Type & Locus & Allele & Sample & Chromosome & Rp & Significance & Table \# \\
Vumber & Locus & Value & & \\
\hline Enzyme & $\begin{array}{l}\text { ACP1 } \\
(1)\end{array}$ & $\mathrm{a}$ & 22 & $2 \mathrm{p} 25$ & .726 & $* * *$ & 2 \\
\hline & $\begin{array}{l}\text { ADA } \\
(2)\end{array}$ & 1 & 24 & $20 \mathrm{q} 13.11$ & .832 & $* * *$ & 6 \\
\hline & $\begin{array}{l}\text { AK 1 } \\
(3)\end{array}$ & 1 & 24 & $9 \mathrm{q} 34.13$ & .758 & $* * *$ & 7 \\
\hline & C1 (4) & $\mathrm{u}$ & 18 & $3 \mathrm{q} 25.2$ & .84 & $* * *$ & 20 \\
\hline & ESD & 1 & 22 & $13 \mathrm{q} 14.2$ & .695 & $* *$ & 29 \\
\hline & $(5)$ & & & & & & \\
\hline \\
\hline
\end{tabular}




\begin{tabular}{|c|c|c|c|c|c|c|c|}
\hline Protein & PI (9) & M & 20 & $14 \mathrm{q} 32.1$ & .835 & $* * *$ & $77,77.1$ \\
\hline & $\begin{array}{l}\text { Gc } \\
(10)\end{array}$ & Gr2 & 28 & $4 \mathrm{q} 12$ & .794 & $* * *$ & $104,104.1$ \\
\hline & $\begin{array}{l}\text { HPA } \\
(11)\end{array}$ & 2 & 25 & $16 \mathrm{q} 22.1$ & .649 & $* * *$ & $105,105.1$ \\
\hline & $\begin{array}{l}\text { BF } \\
(12)\end{array}$ & $\mathrm{S}$ & 26 & $6 \mathrm{p} 21.3$ & .902 & $* * *$ & 127 \\
\hline & $\mathrm{T}(13)$ & $\mathrm{C}$ & 26 & $6 \mathrm{p} 22.2$ & .807 & $* * *$ & 136 \\
\hline $\begin{array}{l}\text { Blood } \\
\text { Gp. }\end{array}$ & $\begin{array}{l}\mathrm{ABO} \\
(14)\end{array}$ & $\mathrm{O}$ & 25 & $9 \mathrm{q} 34$ & .8 & $* * *$ & 141 \\
\hline & $\begin{array}{l}\mathrm{LU} \\
(15)\end{array}$ & $\mathrm{Lu}(\mathrm{a})$ & 16 & 19p13 & .686 & $* *$ & 154 \\
\hline & $\begin{array}{l}\text { MNS } \\
(16)\end{array}$ & MS & 23 & $4 \mathrm{q} 28$ & .773 & $* * *$ & 156 \\
\hline & $\mathrm{P}(17)$ & P1 & 22 & $3 \mathrm{q} 25$ & .636 & $* *$ & 158 \\
\hline & $\begin{array}{l}\text { RH } \\
(18)\end{array}$ & cde & 23 & $1 \mathrm{q} 36.2$ & .558 & $* *$ & 159 \\
\hline Misc & $\begin{array}{l}\text { PTC } \\
(19)\end{array}$ & $\mathrm{T}$ & 20 & $7 \mathrm{q} 24$ & .765 & $* * *$ & 217 \\
\hline
\end{tabular}

$* *=<.01$

$* * *=<.001$ 
(1) Acid Phosphotase (ACP1); (2) Adenosine Deaminase (ADA); (3) Adenylate Kinase 1; (4) Cholinesterase (serum) 1; (5) Esterase D (ESD); (6) Glutamic Pyruvate Transaminase (GPT); (7) Glycoxalase I (GLO1); (8) Phosphogluconate dehydrogenase (PGD); (9) Alpha-1 Antitrypsin (PI); (10) VDBG (Gc); (11) Haptoglobin, alpha (HPA); (12) Properdin Factor B (BF); (13) Transferrin; (14) Landsteiner ABO; (15) Lutheran (LU); (16) MNSs (MNS); (17) P System (P); (18) rhesus system (RH); (19) PTC Sensitivity. 
Figure 1. Lactose Persistence Frequency by C282Y Allele Frequency. Linear Regression: $\mathrm{r}=.86, \mathrm{r}^{2}=.68, \mathrm{t}=9.23 ; \mathrm{F}=85.19$, d.f. $=41, \mathrm{p}<0.0001$

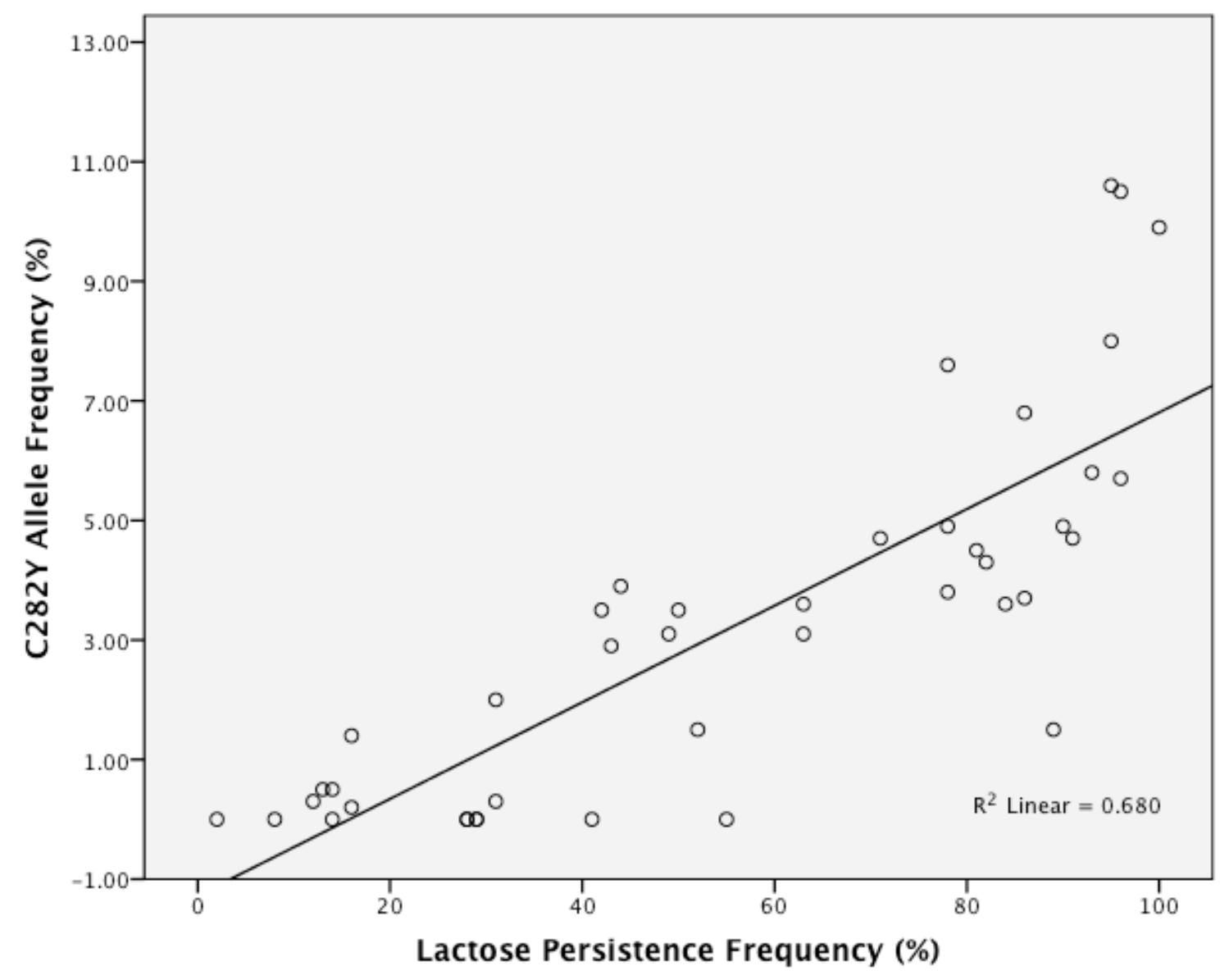

